\title{
Internal Loading of Phosphorus from Bottom Sediments of Two Meso-eutrophic Lakes
}

\author{
Katarzyna Kowalczewska-Madura ${ }^{1} \mathbb{D} \cdot$ Anna Kozak $^{1} \cdot$ Martyna Dera $^{1} \cdot$ Ryszard Gołdyn $^{1}$
}

Received: 25 July 2018 / Revised: 18 December 2018 / Accepted: 4 January 2019 / Published online: 18 January 2019

(c) The Author(s) 2019

\begin{abstract}
The aim of the study was to determine the seasonal and spatial variability of phosphorus release from bottom sediments of two lakes in Poland (Wielkopolska Region): Lusowskie Lake and Prawe Lake. The comparison of results from these two lakes could have been reliably made, because they were characterized by a similar trophic state (meso-eutrophic), were located in the same climatic zone, and were examined at the same time but differed in terms of morphometry (area, depth, and shape) as well as land use of catchment area. These dimictic lakes were characterized by hypolimnetic oxygen deficits in summer. The internal loading of phosphorus was analysed on the basis of ex situ experiments with intact cores of bottom sediments sampled at two stations, situated in the profundal (the deepest place in the lake) and in the littoral (2.0 m depth). The results indicated that a higher phosphorus load was released from bottom sediments in the profundal zone than in the littoral zone of both lakes. Phosphorus release from the profundal zone was twofold higher in Prawe Lake than in Lusowskie Lake. It reached $2.6 \mathrm{mg} \mathrm{P} \mathrm{m}^{-2} \mathrm{~d}^{-1}$ in spring and winter in the larger and deeper Lusowskie Lake, compared to $6.04 \mathrm{mg} \mathrm{P} \mathrm{m}^{-2} \mathrm{~d}^{-1}$ in autumn in the smaller and shallower Prawe Lake. In the littoral zone, phosphorus release reached $1.67 \mathrm{mg} \mathrm{P} \mathrm{m}^{-2} \mathrm{~d}^{-1}$ and $0.16 \mathrm{mg} \mathrm{P} \mathrm{m}^{-2} \mathrm{~d}^{-1}$ in both lakes, respectively. Differences in phosphorus internal loading between the lakes were due to differences in the stability of thermal stratification, time of water mixing and oxygen concentration in the depth profile of the lake.
\end{abstract}

\section{Article Highlights}

- Seasonal and spatial changes of $P$ internal loading from bottom sediments in meso-eutrophic lakes is presented

- P release from the profundal zone was twofold higher in Prawe than in Lusowskie Lake.

- Differences in $\mathbf{P}$ internal loading between the lakes were due to differences in the stability of thermal stratification, time of water mixing, and oxygen concentration

Keywords Phosphorus $\cdot$ Bottom sediments $\cdot$ Meso-eutrophic lake $\cdot$ Internal loading

\section{Introduction}

Lake bottom sediments are very important part of the water ecosystem. They can play a role of sink or source of phosphorus $(\mathrm{P})$, depending on temperature, oxygen conditions, $\mathrm{pH}$, redox potential and gradient of $\mathrm{P}$ concentration at the sediment-water interface. The presence of macrophytes and type of chemical compounds in which $\mathrm{P}$ is present in

Katarzyna Kowalczewska-Madura

madura@amu.edu.pl

1 Department of Water Protection, Faculty of Biology, Adam Mickiewicz University, Umultowska 89, 61-614 Poznan, Poland the sediments are also important (Boström et al. 1988; Stephen et al. 1997; Søndergaard et al. 2001, 2002; Hupfer and Lewandowski 2005). Internal loading as P released from sediment surfaces often represents the main summer P load to lakes and reservoirs and can have an immense effect on their water quality (Kowalczewska-Madura and Gołdyn 2010).

The potential $P$ source in the surface layer of sediments is very large in comparison with the pool in the water column. This means that if even only a very small amount is released, it will have significant impact on the $\mathrm{P}$ concentration in the lake water (Petterson 1998). In general, P release from sediments should differ significantly between shallow and deep lakes (Boström et al. 1982; Kowalczewska-Madura 
et al. 2015). Internal loading is of fundamental importance in large and shallow lakes, where even low wind velocities can cause a considerable resuspension of matter deposited on the lake bed (Håkanson 2004). Thermal stratification in deep lakes largely prevents interactions between the epilimnion and the colder hypolimnion and bottom sediments in summer. However, oxygen depletion and redox potential decrease can stimulate $P$ release from the fraction bound with iron (Søndergaard et al. 2002).

The epilimnion can appear to be untouched by internal load in stratified lakes during summer. Total phosphorus (TP) and soluble reactive phosphorus (SRP) concentrations increase in the hypolimnion during summer (when is formed thermal stratification). If such elevated $P$ concentrations are associated with anaerobic conditions and the prevalence of some reduced substances (Fe and $\mathrm{Mn}$ compounds, $\mathrm{NH}_{4}$, hydrogen sulphide, and methane), the occurrence of internal $\mathrm{P}$ load is certain. Internal load affects surface water quality in shallow polymictic lakes even in summer, but in stratified lakes mostly during thermocline erosion and turnover in autumn (Nürnberg 2009).

Osgood (1988) proposed a morphometric index, to predict vertical $P$ transport in lakes during mixing caused by strong winds. Such mixing could introduce $P$ rich waters to the entire water column. According to Mataraza and Cooke (1997), lakes with a high Osgood Index could have significant vertical P transport if there is a steep P gradient in the water column.

Currently, hydrobiological research concerning the comparison of the internal P loading in dimictic lakes of various morphometric conditions, such as depth and surface area is scarce, especially for lakes that do not differ in their trophic status. This last condition is very important because internal $\mathrm{P}$ loading significantly depends on the lake trophic state (Kowalczewska-Madura et al. 2015). According to Carey and Rydin (2011), this is mainly connected with sediment $P$ burial processes, which are very effective in oligotrophic lakes, allowing mobile $\mathrm{P}$ to be permanently retained. Eutrophic lakes, however, with a high concentration of potentially mobile $\mathrm{P}$ in sediment are less able to bind $\mathrm{P}$ in its surficial layer and are characterized by a greater $\mathrm{P}$ release to the water column.

The aim of this study was to determine the differences in seasonal and spatial variability of internal $P$ release/accumulation as a result of differences in the morphometric characteristics of two lakes, especially their surface area and depth. To eliminate the influence of trophic conditions, two lakes were chosen with a similar trophic status defined as mesoeutrophic. This is a new approach, because this manuscript compares the results for internal phosphorus loading for two lakes tested at the same time, in the same climatic zone, and with similar trophic state but differing in morphometric features.

\section{Materials and Methods}

Sediment internal P loading was studied in two lakes in the Wielkopolska Region of Poland, i.e., in Lusowskie Lake and Prawe Lake.

Lusowskie Lake is located about $6 \mathrm{~km}$ west of the city of Poznań $\left(52^{\circ} 25^{\prime} \mathrm{N}, 16^{\circ} 40^{\prime} \mathrm{E}\right)$. Its surface area is 121.9 ha, maximum depth $19.5 \mathrm{~m}$, and mean depth $8.6 \mathrm{~m}$. The total area of the lake's catchment is about $19.1 \mathrm{~km}^{2} .48 .6 \%$ of the adjacent area is occupied by arable fields, $31.6 \%$ by forests, $12.3 \%$ by meadows, and $7.5 \%$ by rural and recreational buildings. The lake is supplied by 6 drainage ditches from recreational and agricultural areas (Pułyk et al. 2001). The Sama River flows out from the western part of the lake. This is a dimictic, thermally stratified lake, with three well-formed layers: epilimnion, metalimnion, and hypolimnion.

Prawe Lake is located in the valley of the Cybina River $\left(52^{\circ} 27^{\prime} \mathrm{N}, 17^{\circ} 09^{\prime} \mathrm{E}\right)$. It is a small, kettle-shaped, dimictic lake with a surface area of about 5 ha and a maximum depth of $7 \mathrm{~m}$. Its catchment area is dominated by agriculture (Gołdyn and Grabia 1998); however, the part adjacent to the lake is covered by forest and agricultural fallow.

Samples of water and bottom sediments from both lakes were taken at two stations, which represented two different zones in analysed lakes. They were taken once in every season (spring-March, summer-August, autumnOctober, and winter-February), starting from March 2008 until February 2009. Station 1 was located in the deepest place (profundal zone) and station 2 at a water depth of about $2 \mathrm{~m}$ (littoral zone) in both lakes (Fig. 1).

Water temperature, $\mathrm{pH}$, conductivity, and oxygen concentration were measured in situ in a depth profile at every station, using a YSI 556MPS-meter, and water transparency was measured with a Secchi disc. Physico-chemical and biological samples were taken in the deepest part (station 1) of the lakes, in a depth profile: every meter from the surface layer to the bottom in Prawe Lake and from the surface layer, $4 \mathrm{~m}, 9 \mathrm{~m}, 14 \mathrm{~m}$, and $18 \mathrm{~m}$ in Lusowskie Lake, using a bathometer with a volume of $5 \mathrm{~L}$. Chemical analyses which included the concentration of ammonium nitrogen $\left(\mathrm{N}-\mathrm{NH}_{4}\right)$, nitrite nitrogen $\left(\mathrm{N}-\mathrm{NO}_{2}\right)$, nitrate nitrogen $\left(\mathrm{N}-\mathrm{NO}_{3}\right)$, soluble reactive phosphorus (SRP), and total phosphorus (TP) were done according Polish standards (Elbanowska et al. 1999). Total suspended solids (TSS) were analysed with the weight method and chlorophyll- $a$ (Chl- $a$ ) with the Lorenzen method (1967).

Phytoplankton samples were fixed with Lugol's solution. They were analysed in the laboratory using an Olympus CH-20 microscope with a magnification of $400 \times$. The abundance of the phytoplankton (specimen number in $1 \mathrm{~mL}$ ) was determined applying the Sedgwick-Rafter 

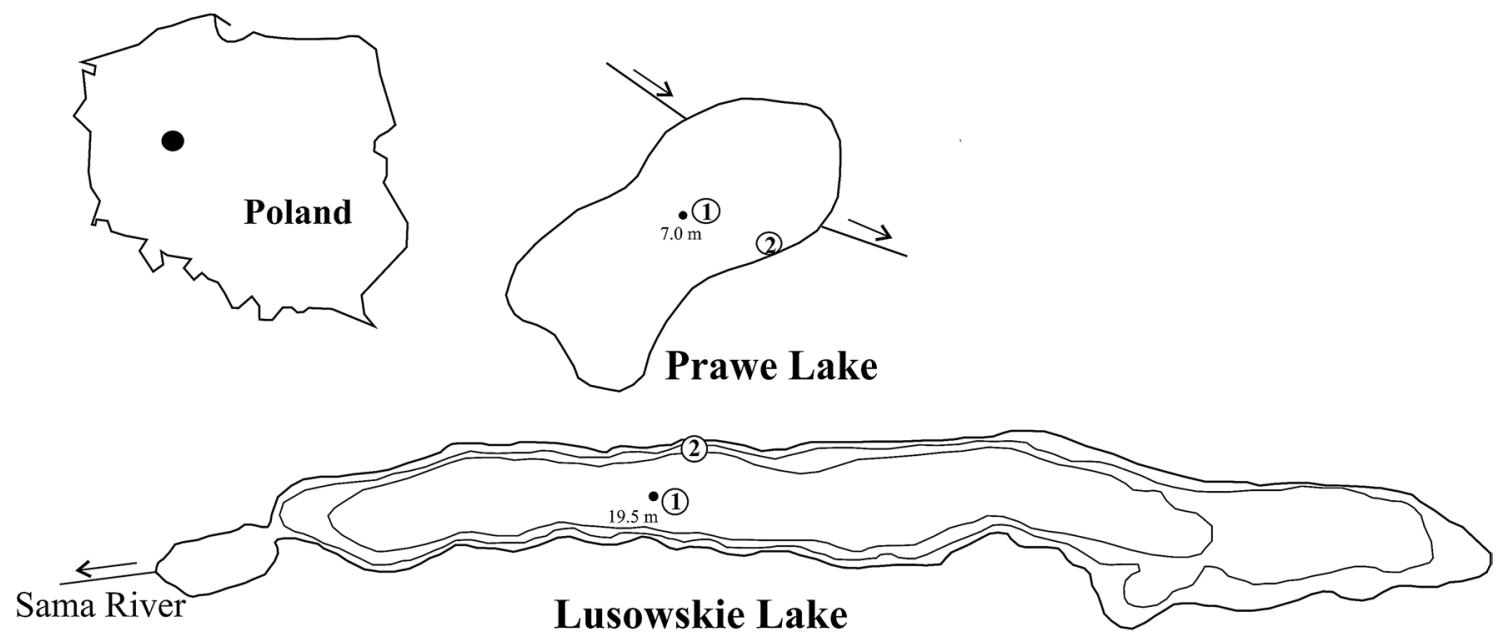

sampling station

Fig. 1 Location of sampling stations in Prawe Lake and Lusowskie Lake. Acc. to Pułyk et al. (2001), modified

chamber. In addition, the Shannon-Weaver phytoplankton diversity index was counted using the PAST program (https://folk.uio.no/ohammer/past/) and functional classification of phytoplankton assemblages was performed according to Reynolds et al. (2002) and Padisak et al. (2009).

Trophic conditions were estimated in accordance with criteria proposed by Carlson (1977). The TSI index was calculated on the basis of variables such as transparency, chlorophyll- $a$, and TP content. The Osgood Index for Prawe and Lusowskie Lake was calculated according to the equation proposed by Osgood (1988) (mean depth over square root of surface).

The upper layer of the bottom sediments was sampled using a Kajak tube sampler, where we analysed organic matter and total phosphorus content. Organic matter content (\%) was analysed by drying each sample to a constant weight and combustion at $550{ }^{\circ} \mathrm{C}$ (Myślińska 2001). TP concentration was analysed in the dry residue after dissolving in hydrochloric acid. $\mathrm{P}$ was fractionated in fresh sediment samples according to the modified protocol proposed by Psenner (Psenner et al. 1988). The fractions were: loosely bound (labile) $\mathrm{P}\left(\mathrm{NH}_{4} \mathrm{Cl}-\mathrm{P}\right)$, redox-sensitive $\mathrm{P}$ bound with iron (BD-P), $\mathrm{P}$ bound with aluminum, and organic matter (NaOH-P and NaOH-NRP, respectively), $\mathrm{P}$ bound with calcium and magnesium (HCl-P), and the residual $\mathrm{P}$ (Res-P), which was calculated as the difference between total $\mathrm{P}$ and the sum of the first four fractions. In addition, we sampled intact cores of bottom sediments $20 \mathrm{~cm}$ in length (from the profundal) and $15 \mathrm{~cm}$ in length (from the littoral). The samples were divided into $5 \mathrm{~cm}$ sections, from which the content of total phosphorus and individual phosphorus fractions and organic matter were analysed.

Pore waters from bottom sediments were obtained after centrifugation in a laboratory centrifuge ( $1 \mathrm{~h}$ at $3000 \mathrm{rpm}$ ). SRP concentration was analysed in the supernatant using the molybdate method with ascorbic acid as a reducer and TP with the same method after mineralization (PN-EN ISO 6878:2006). The same $P$ forms were analysed in water overlying the sediment at two stations.

P-exchange analyses between bottom sediments and overlying water ( $\mathrm{P}$ release or $\mathrm{P}$ accumulation) were done using ex situ (laboratory) experiments. We collected intact cores of bottom sediments $15 \mathrm{~cm}$ length, together with $25 \mathrm{~cm}$ of overlying water in transparent tubes at both stations in three replicates. They were incubated in laboratory room in darkness in thermal and oxic conditions similar to the natural conditions within the lake during sampling. Anaerobic conditions in the overlying water in the tubes were maintained by closing tubes with rubber stoppers. In experiments with aerobic conditions, they were simply left open to the atmosphere. When the oxygen concentration decreased in time of experiment (below $4 \mathrm{mgO}_{2} \mathrm{~L}^{-1}$ ), additional aeration was used. Every 2-3 days over a 2 week period, samples of overlying water were collected from the tubes above the sediments $(50 \mathrm{~mL})$ and the concentration of TP was analysed spectrophotometrically with ascorbic acid as a reducer. Water volume in every tube was replenished with $50 \mathrm{~mL}$ of water, which was sampled at the same station from the over-bottom layer. We determined the P concentration in the overlying water of individual cores of bottom sediment. Next, we calculated the difference in $\mathrm{P}$ concentration between successive days of the experiment expressed in $\mathrm{mg} \mathrm{P} \mathrm{L}^{-1}$. The next step 
was to calculate the amount of phosphorus released per day from the unit area $\left(1 \mathrm{~m}^{2}\right)$, taking into account the surface of the sediment core and the volume of water above the each sediment core. The number of days between successive overlying water sampling was also taken into account. Finally, we summed the amount of released (positive values) or accumulated (negative values) phosphorus in bottom sediments, and dividing by the number of days of the experiment, we obtained the result expressed in $\mathrm{mg} \mathrm{P} \mathrm{m}^{-2} \mathrm{~d}^{-1}$. This type of conversion of the experimental research results has been presented in the earlier publications (Kowalczewska-Madura et al. 2015, 2017, 2019). The physico-chemical parameters (water temperature, dissolved oxygen concentration, $\mathrm{pH}$, and conductivity) in overlying water in the sediment cores were measured before water sampling from the tubes with a Multi 350i-meter (WTW).

Basic statistical calculations were made with STATISTICA version 10.0 software. To confirm the significance of differences between the analysed sediment features in time, non-parametric tests were used, i.e., Mann-Whitney $U$ and Kruskall-Wallis tests.

\section{Results}

\section{Water Quality}

The cumulative TSI index (Carlson 1977) was very similar for both lakes, namely, 142.3 for Lusowskie Lake and 148.9 for Prawe Lake, so the studied lakes should be classified as meso-eutrophic. The Osgood Index was 10.5 for Prawe Lake and 7.8 for Lusowskie Lake, so they are lakes with quite stable thermal stratification. As a result, in both lakes in summer, a clear thermal and oxygen gradient was found in the water column between the epilimnion and metalimnion. Furthermore, oxygen depletion was observed in the hypolimnion, i.e., from 9 to $18 \mathrm{~m}$ in Lusowskie Lake and from 5 to $7 \mathrm{~m}$ in Prawe Lake (Fig. 2). Good oxygenation of water overlying the bottom sediments occurred in Lusowskie Lake only in spring because the autumn overturn was very limited. Prawe Lake, although characterized by a higher Osgood Index, had intensive overturn events both in spring and autumn (Table 1).

The concentration of chlorophyll- $a$ in the surface water layer was lower in Lusowskie Lake (below $7 \mu \mathrm{g} \mathrm{L}^{-1}$ ) than in Prawe Lake (up to almost $13 \mu \mathrm{g} \mathrm{L}^{-1}$ ). They were similar in the case of suspended matter. In winter, Secchi depth reached $7.0 \mathrm{~m}$ in Lusowskie Lake and did not exceed $3.8 \mathrm{~m}$ in Prawe Lake, and a similar difference was also found in summer, i.e., $2.4 \mathrm{~m}$ and $2.1 \mathrm{~m}$, respectively. $\mathrm{pH}$ reached a maximum of 8.39 in Prawe Lake in spring and was similar in both lakes in winter. The minimum was observed in summer in water overlying the sediments, i.e., 7.21 in
Prawe Lake and 6.28 in Lusowskie Lake. Higher conductivity was recorded in Prawe Lake than in Lusowskie Lake (Table 1).

TP concentration in water overlying the sediments reached a maximum of $0.25 \mathrm{mg} \mathrm{P} \mathrm{L}^{-1}$ in Lusowskie Lake in winter and $0.42 \mathrm{mg} \mathrm{P} \mathrm{L}^{-1}$ in Prawe Lake in summer. These concentrations in Prawe Lake did not exceed $0.1 \mathrm{mg} \mathrm{P} \mathrm{L}^{-1}$ in other seasons, whereas in Lusowskie Lake, higher concentrations (over $0.1 \mathrm{mg} \mathrm{P} \mathrm{L}^{-1}$ ) were recorded in autumn from the depth $14 \mathrm{~m}$ to the bottom of the lake and in winter near the bottom (Fig. 3a, b).

The concentration of mineral nitrogen (as a sum of three dissolved inorganic forms: ammonium, nitrite, and nitrate nitrogen) reached a maximum in the hypolimnion in summer in Prawe Lake and in autumn in Lusowskie Lake (Fig. 4).

Among these forms nitrate dominated in spring and in Lusowskie Lake also in winter, while ammonium nitrogen in summer and autumn. Although nitrates were dominant mainly in spring, they were present in all seasons. In summer, they were present in the whole water column of Lusowskie Lake, while they were exhausted in the water overlying the sediments of Prawe Lake (Fig. 4).

Statistically significant differences (Mann-Whitney $U$ test) between the analysed physico-chemical and biological parameters of water between both lakes were found only for chlorophyll- $a$ over the bottom and for the suspended matter and conductivity at the surface and over the bottom $(p<0.05)$.

Both lakes were characterized by slightly different species compositions and phytoplankton abundance. Members of the C (Stephanodiscus, Nitzschia), J (Crucigenia, Scenedesmus), P (Closterium), X2 (Rhodomonas), X3 (Chrysococcus, Koliella), and Y (Cryptomonas) functional groups were significant/dominant in both studied lakes. They had a high percentage (maximal values reached $14-82 \%$ ) in the total abundance of phytoplankton. In addition, representatives of codon D (Fragilaria), F (Oocystis), and X1 (Didimocystis) were dominant in Lusowskie Lake, while S1 (Planktothrix) and Lo (Peridinium) dominated in Prawe Lake. Codons D, F, and X1, recorded in Lusowskie Lake, reached $15 \%, 24 \%$, and $43 \%$ of phytoplankton abundance, respectively. Codons S1 and Lo, which dominated only in Prawe Lake, reached 64\% and $12 \%$. A higher abundance of phytoplankton was observed in Prawe Lake, where it reached 9000 spec. $\mathrm{mL}^{-1}$ in summer, while it did not exceed 5000 spec. $\mathrm{mL}^{-1}$ in Lusowskie Lake (Fig. 5a, b). The dominant species in Lusowskie Lake in summer were Chlorophyceae (Didimocystis sp. and Scenedesmus ecornis) with a small proportion of Cyanobacteria (Aphanocapsa incerta). In Prawe Lake, from the surface to $3 \mathrm{~m}$ Chlorophyceae (Crucigenia sp.) dominated in summer but from 4 to $6 \mathrm{~m}$ Cyanobacteria (Planktothrix agardhii). A slightly higher value of the Shannon-Weaver diversity index was found in Lusowskie Lake, from 0.85 to 2.58, while in Prawe Lake, it ranged from 0.78 to 2.36 . 
Fig. 2 Temperature and oxygen concentration in Prawe Lake (a, c) and Lusowskie Lake (b, d)

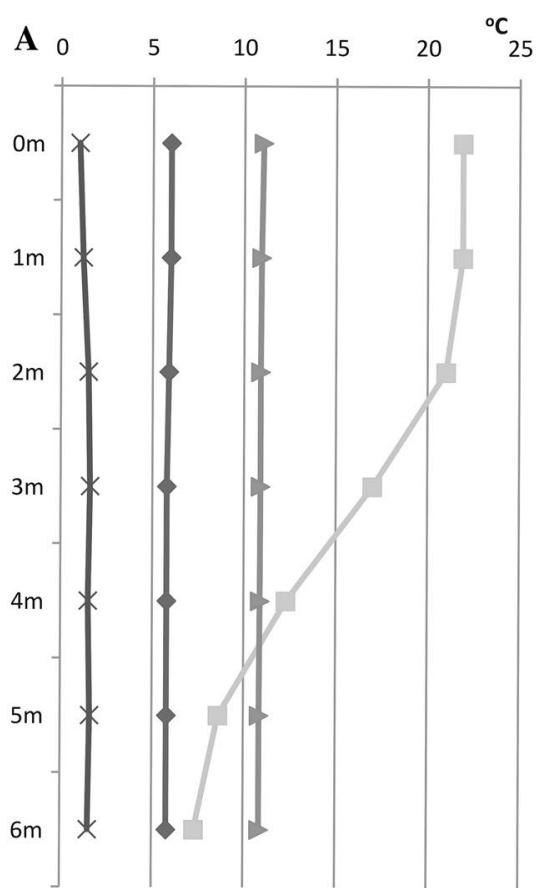

C

Om

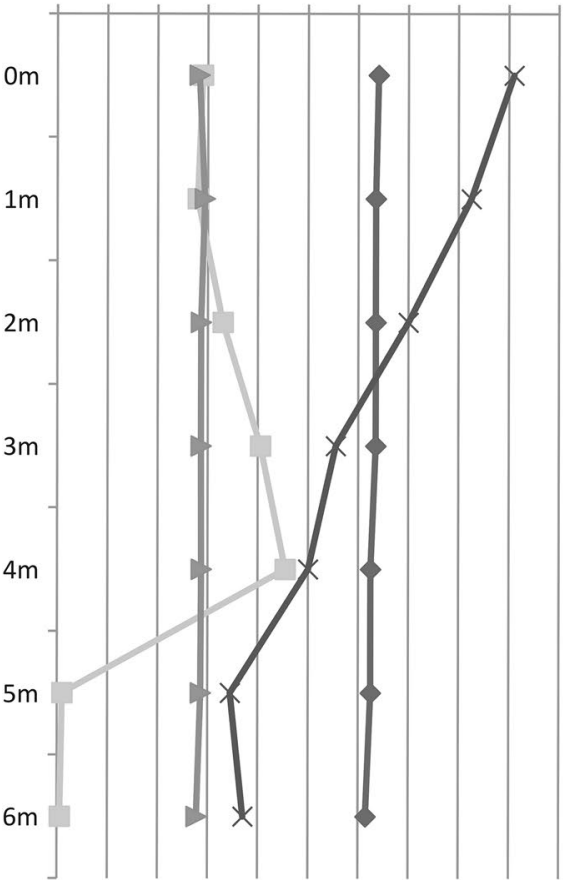

B

\begin{tabular}{lllll}
0 & 5 & $10^{\circ}$ & & \\
& & & & \\
\hline
\end{tabular}

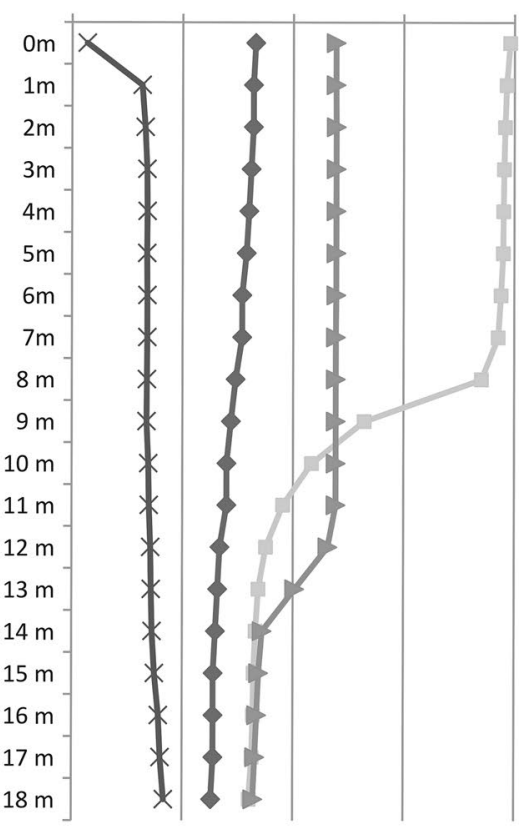

D

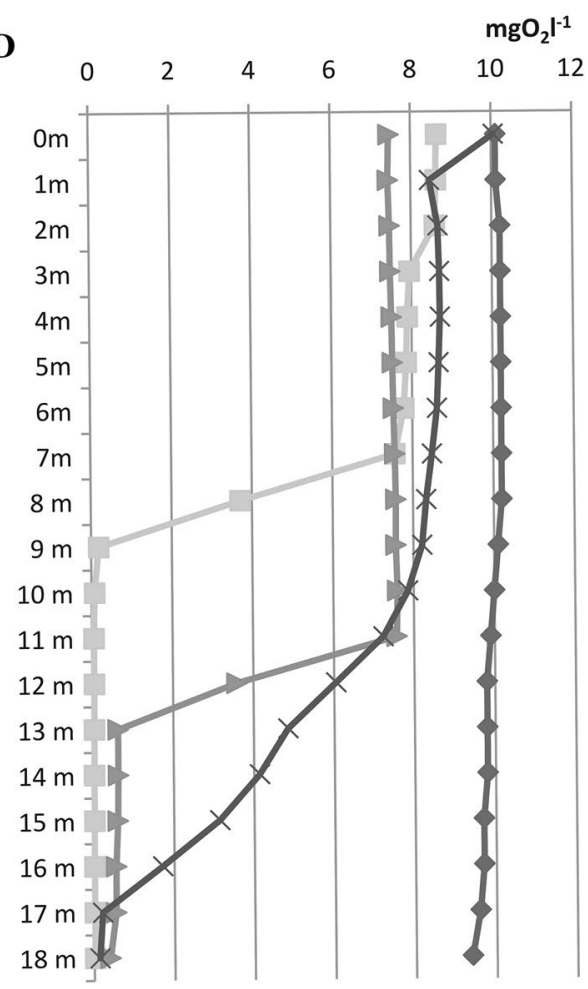

$\rightarrow$ Spring - - Summer $\rightarrow$ Autumn $\multimap$ Winter 
Table 1 Physico-chemical and biological variables of water in Prawe lake and Lusowskie lake at station 1 from March 2008 to February 2009 at the surface and in water layer overlying the sediments and mean $( \pm \mathrm{SD})$

\begin{tabular}{|c|c|c|c|c|c|c|c|c|c|}
\hline \multirow[t]{2}{*}{ Parameter } & \multirow[t]{2}{*}{ Season } & \multicolumn{4}{|l|}{ Prawe Lake } & \multicolumn{4}{|c|}{ Lusowskie Lake } \\
\hline & & Surface $(0 \mathrm{~m})$ & Mean (SD) & Bottom (6 m) & Mean (SD) & Surface $(0 \mathrm{~m})$ & Mean (SD) & $\begin{array}{l}\text { Bottom } \\
(18 \mathrm{~m})\end{array}$ & Mean (SD) \\
\hline \multirow{4}{*}{$\begin{array}{l}\text { Chlorophyll- } a \\
\left(\mu \mathrm{g} \mathrm{L}^{-1}\right)\end{array}$} & Spring & 9.3 & $10.1(3.3)$ & 10.8 & $14.5(4.8)$ & 3.2 & $4.3(1.9)$ & 1.7 & $0.8(0.7)$ \\
\hline & Summer & 5.8 & & 21.5 & & 6.6 & & 0.7 & \\
\hline & Autumn & 12.6 & & 12.0 & & 5.1 & & 0.9 & \\
\hline & Winter & 12.8 & & 13.6 & & 2.3 & & 0.0 & \\
\hline \multirow{4}{*}{$\begin{array}{l}\text { Suspended } \\
\text { matter (mg } \\
\left.\mathrm{L}^{-1}\right)\end{array}$} & Spring & 5.1 & $3.9(1.3)$ & 4.4 & $4.6(2.2)$ & 1.6 & $1.3(0.6)$ & 0.9 & $0.7(0.1)$ \\
\hline & Summer & 2.9 & & 7.5 & & 1.4 & & 0.7 & \\
\hline & Autumn & 4.8 & & 4.4 & & 1.25 & & 0.75 & \\
\hline & Winter & 2.6 & & 2.2 & & 0.45 & & 1.0 & \\
\hline \multirow{4}{*}{$\begin{array}{l}\text { Conductivity } \\
\left(\mu \mathrm{cm}^{-1}\right)\end{array}$} & Spring & 961 & 945.7 (41.9) & 966 & $982.3(119.3)$ & 771 & $711.0(40.4)$ & 775 & $776.0(43.1)$ \\
\hline & Summer & 998 & & 1028 & & 684 & & 747 & \\
\hline & Autumn & 908 & & 909 & & 692 & & 746 & \\
\hline & Winter & 916 & & 1025 & & 697 & & 838 & \\
\hline \multirow[t]{4}{*}{$\mathrm{pH}$} & Spring & 8.39 & - & 8.32 & - & 8.14 & - & 8.01 & - \\
\hline & Summer & 7.78 & & 7.21 & & 8.05 & & 6.28 & \\
\hline & Autumn & 7.88 & & 7.74 & & 7.98 & & 7.52 & \\
\hline & Winter & 8.35 & & 7.44 & & 8.33 & & 7.21 & \\
\hline \multirow{4}{*}{$\begin{array}{l}\text { Oxygen } \\
\qquad\left(\mathrm{mgO}_{2} \mathrm{~L}^{-1}\right)\end{array}$} & Spring & 12.8 & $9.8(4.1)$ & 11.3 & $3.7(4.5)$ & 10.1 & $9.1(1.3)$ & 9.4 & $2.5(4.6)$ \\
\hline & Summer & 5.8 & & 0.1 & & 8.63 & & 0.02 & \\
\hline & Autumn & 5.7 & & 5.6 & & 7.45 & & 0.6 & \\
\hline & Winter & 18.2 & & 2.7 & & 10.1 & & 0.14 & \\
\hline \multirow{4}{*}{$\begin{array}{l}\text { Transparency } \\
\text { (m) }\end{array}$} & Spring & 2.1 & $2.4(0.9)$ & - & - & 3.7 & $4.2(0.9)$ & - & - \\
\hline & Summer & 2.1 & & - & & 2.4 & & - & \\
\hline & Autumn & 1.7 & & - & & 3.5 & & - & \\
\hline & Winter & 3.8 & & - & & 7.0 & & - & \\
\hline
\end{tabular}

\section{Characteristic of Bottom Sediments}

TP content in bottom sediments of both lakes was higher in the deepest part of the lakes (profundal zone at station 1) than in the littoral zone (station 2) and it fluctuated in the same range between 0.84 and $1.30 \mathrm{mg} \mathrm{P} \mathrm{g}^{-1} \mathrm{DW}$ in Lusowskie Lake and from 0.91 to $1.24 \mathrm{mg} \mathrm{P} \mathrm{g}^{-1} \mathrm{DW}$ in Prawe Lake. The highest values were noted in summer in the profundal zone of both lakes and the lowest in winter in the littoral zone of both lakes (Fig. 6a, Table 2). No statistically significant differences were found between the analysed sites in the lake or between the two lakes (Mann-Whitney $U$ test $p>0.05$ ).

The organic matter content in bottom sediments of the studied lakes ranged from 10.4 to $16.9 \%$ in Lusowskie Lake and from 18.9 to $27.6 \%$ in Prawe Lake. Lower concentration was noted in the littoral zone (station 2) than in the deepest part of the lake (station 1). The highest value was observed in summer in the profundal zone of Prawe Lake, while in autumn in Lusowskie Lake. In the littoral zone of both lakes, the maximum content of organic matter was found in winter (Fig. 6b, Table 2). Statistically significant differences of organic matter content were found between the lakes (Mann-Whitney $U$ test, $p<0.05$ ).

The dominant $\mathrm{P}$ fraction in both lakes was Res-P, i.e., $\mathrm{P}$ that is practically biologically inaccessible. The mean share of that fraction in TP of the profundal zone in both lakes went up to $40.1 \%$. In the littoral zone, however, it was higher in Lusowskie Lake (mean 45.5\%) than in Prawe Lake (mean $32.8 \%$ ) (Fig. 7a, b, Table 2). The mean total share of the fractions with the highest bioavailability $\left(\mathrm{NH}_{4} \mathrm{Cl}-\mathrm{P}, \mathrm{BD}-\mathrm{P}\right.$, and $\mathrm{NaOH}-\mathrm{P})$ was higher in Prawe Lake $(21.2 \%$ at station 1 and $20.1 \%$ at station 2 ) than in Lusowskie Lake (12.4\% and $7.8 \%$, respectively). A higher mean share of the HCl-P fraction (P compounds with calcium and magnesium) was characterized by Lusowskie Lake (in the profundal $17.0 \%$ and in the littoral $27.1 \%$ ) and it was not more than $14.0 \%$ in Prawe Lake (Fig. 7a, b, Table 2). Statistically significant differences were found between the analysed stations in Prawe Lake for fraction $\mathrm{NH}_{4} \mathrm{Cl}-\mathrm{P}$, BD-P, and HCl-P and in Lusowskie Lake only for fraction BD-P and NaOH-NRP (Mann-Whitney $U$ test $p<0.05$ ). Statistically significant differences between 
Fig. 3 Changes of SRP and TP in depth profiles of Prawe Lake (a) and Lusowskie Lake (b)
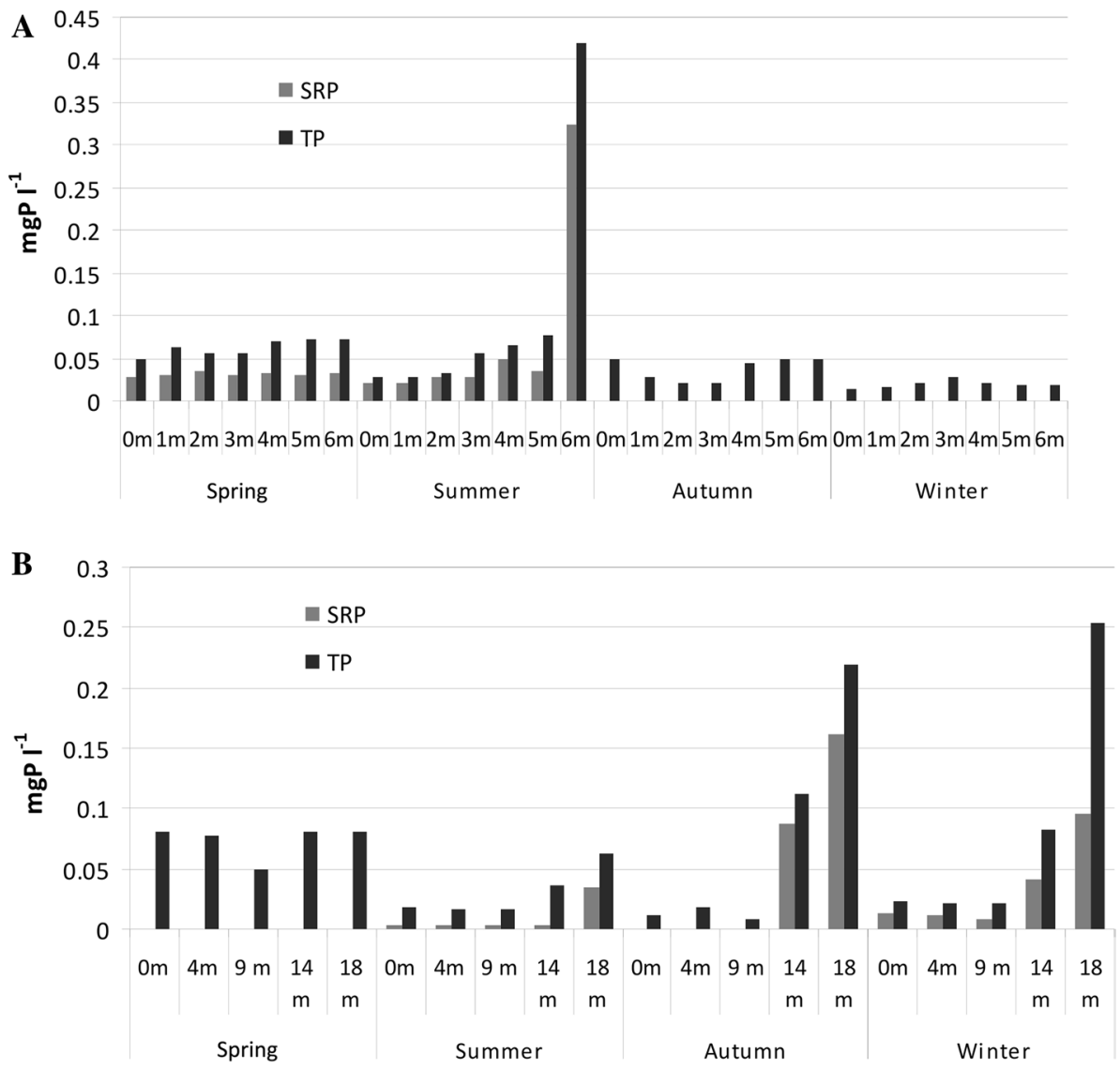

the analysed lakes were found for fraction $\mathrm{NH}_{4} \mathrm{Cl}-\mathrm{P}, \mathrm{BD}-\mathrm{P}$, and HCl-P (Mann-Whitney $U$ test $p<0.05$ ).

The TP concentration in the depth profile of bottom sediments in the profundal zone was similar in both lakes, ranging from 1.13 to $1.35 \mathrm{mg} \mathrm{P} \mathrm{g}^{-1} \mathrm{DW}$ in Prawe Lake and from 1.18 to $1.26 \mathrm{mg} \mathrm{P} \mathrm{g}^{-1} \mathrm{DW}$ in Lusowskie Lake. The dominant fraction of TP was Res-P, whose mean share in Prawe Lake was $40 \%$ and in Lusowskie Lake $42.5 \%$ (Fig. 8a). It was lower in the littoral zone of both lakes and ranged from 0.96 to $1.23 \mathrm{mg} \mathrm{P} \mathrm{g}^{-1} \mathrm{DW}$ in Prawe Lake and from 0.74 to 1.0 $\mathrm{mg} \mathrm{P} \mathrm{g}^{-1} \mathrm{DW}$ in Lusowskie Lake. Res-P was also the dominant fraction in this zone, as the mean value in Prawe Lake was $46.2 \%$ and in Lusowskie Lake $49.1 \%$ (Fig. 8b).

The content of organic matter in the depth profile of the bottom sediments of both lakes was higher in the profundal zone than in the littoral zone. The highest mean value was recorded in the profundal of Prawe Lake and the lowest in the littoral zone of Lusowskie Lake (Fig. 8c, d).

The concentrations of SRP and TP in the water overlying the sediments were higher in the profundal than in the littoral zones of both lakes (Table 2). They reached $0.95 \mathrm{mg} \mathrm{P} \mathrm{L}^{-1}$ and $0.50 \mathrm{mg} \mathrm{P} \mathrm{L}^{-1}$ in Lusowskie Lake, and they did not exceed $0.36 \mathrm{mg} \mathrm{P} \mathrm{L}^{-1}$ and $0.18 \mathrm{mg} \mathrm{P} \mathrm{L}^{-1}$ in Prawe Lake, respectively (Fig. 9a). Statistically significant differences between the analysed stations (Mann-Whitney
$U$ test $p<0.05)$ both for SRP and for TP were found only in Prawe Lake, but they were also noted between the analysed lakes (Mann-Whitney $U$ test $p<0.05$ ).

Higher SRP and TP concentrations in the pore waters of both lakes were observed in the profundal than in the littoral zone (Table 2). The concentration of TP reached 2.61 mg P L ${ }^{-1}$ in Lusowskie Lake and $2.03 \mathrm{mg} \mathrm{P} \mathrm{L}^{-1}$ in Prawe Lake. A higher concentration was also noted in the littoral zone in Lusowskie Lake (up to $0.96 \mathrm{mg} \mathrm{P} \mathrm{L}^{-1}$ ) compared to Prawe Lake (up to $0.64 \mathrm{mg} \mathrm{P} \mathrm{L}^{-1}$ ). SRP and TP concentration in pore waters increased from spring to winter in Lusowskie Lake, but in the profundal zone of Prawe Lake, they increased only from spring to autumn and in the littoral zone even decreased (Fig. 9b). There were statistically significant differences between the analysed stations in both lakes and between the analysed lakes (Mann-Whitney $U$ test $p<0.05)$.

The results of ex situ experiments revealed that $P$ release from the bottom sediments was higher in the deepest part of the lake than in the littoral zone in both lakes. The physico-chemical variables of water overlying the sediments of the collected cores during the experiments are presented in Table 3.

A predominance of $\mathrm{P}$ release over its accumulation in bottom sediments was observed in all seasons at both stations in 
Fig. 4 Concentration of ammonium nitrogen $\left(\mathrm{N}-\mathrm{NH}_{4}\right)$, nitrite $\left(\mathrm{N}-\mathrm{NO}_{2}\right)$ and nitrate nitrogen $\left(\mathrm{N}-\mathrm{NO}_{3}\right)$ in depth profile of Prawe Lake (a) and Lusowskie Lake (b)
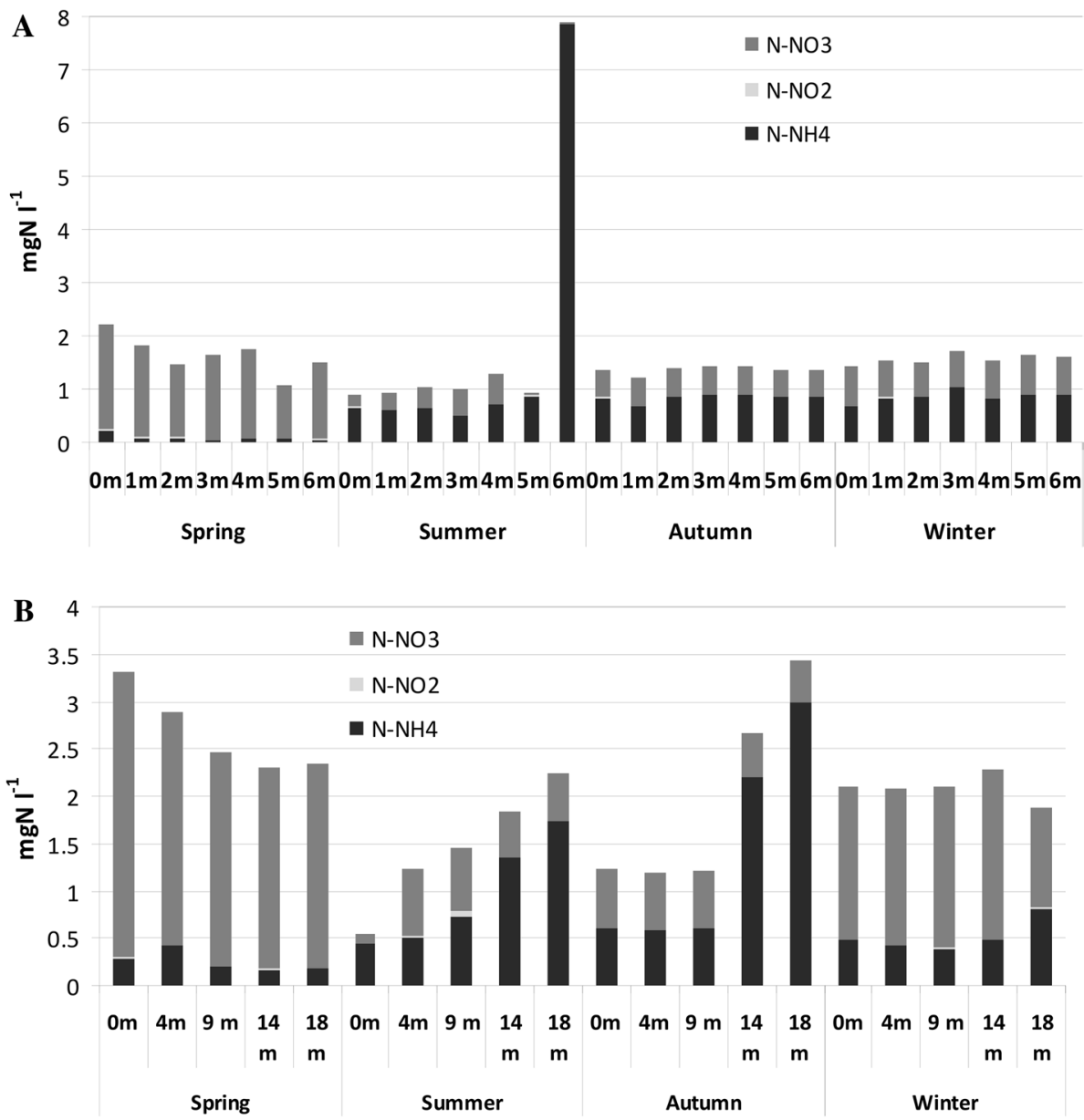

Lusowskie Lake (Table 4). The lowest P release from bottom sediments at station 1 (profundal zone) was noted in autumn $1.16 \mathrm{mg} \mathrm{P} \mathrm{m}^{-2} \mathrm{~d}^{-1}$. It was slightly higher in other seasons, and the maximum value $\left(2.6 \mathrm{mg} \mathrm{P} \mathrm{m}^{-2} \mathrm{~d}^{-1}\right)$ was noted both in spring and in winter. Clearly lower $\mathrm{P}$ release values were found in the littoral zone (station 2). The highest release 1.67 $\mathrm{mg} \mathrm{P} \mathrm{m}{ }^{-2} \mathrm{~d}^{-1}$ occurred there in summer and the lowest 0.11 mg P m ${ }^{-2} \mathrm{~d}^{-1}$ in autumn (Table 4 ).

A predominance of $\mathrm{P}$ release from bottom sediments to overlying water layer over its accumulation was also noted in all seasons in Prawe Lake but only at station 1 . The maximum occurred in autumn, reaching $6.04 \mathrm{mg} \mathrm{P} \mathrm{m}^{-2} \mathrm{~d}^{-1}$, and the minimum in spring $2.53 \mathrm{mg} \mathrm{P} \mathrm{m}^{-2} \mathrm{~d}^{-1}$. Net $\mathrm{P}$ retention $0.15 \mathrm{mg} \mathrm{P} \mathrm{m}^{-2} \mathrm{~d}^{-1}$ in bottom sediments at station 2 (littoral zone) was noted in autumn, whereas low $\mathrm{P}$ release was observed in the other seasons, with the maximum in winter $0.16 \mathrm{mg} \mathrm{P} \mathrm{m}^{-2} \mathrm{~d}^{-1}$ (Table 4).

A comparison of mean values of $\mathrm{P}$ release/accumulation from bottom sediments of both lakes showed that it was higher in the deepest part of the lakes compared to the littoral zones. The mean release was twofold higher in Prawe Lake $\left(4.11 \pm 1.6 \mathrm{mg} \mathrm{P} \mathrm{m}^{-2} \mathrm{~d}^{-1}\right)$ than in Lusowskie Lake $\left(2.08 \pm 0.7 \mathrm{mg} \mathrm{P} \mathrm{m}^{-2} \mathrm{~d}^{-1}\right)$. However, a higher value was noted in the littoral zone of Lusowskie Lake $(0.61 \pm 0.7$ $\left.\mathrm{mg} \mathrm{P} \mathrm{m}^{-2} \mathrm{~d}^{-1}\right)$ than in Prawe Lake $\left(0.03 \pm 0.11 \mathrm{mg} \mathrm{P} \mathrm{m}^{-2}\right.$ $\mathrm{d}^{-1}$ ) (Table 4). Statistically significant differences were found only for Prawe Lake between analysed stations (Mann-Whitney $U$ test $p<0.05$ ), and between the analysed lakes (Mann-Whitney $U$ test $p>0.05$ ).

\section{Discussion}

The results of the experiments allowed an analysis of both seasonal and spatial variability of $P$ release in two lakes with similar trophy but different morphometry (especially surface area and depth). Both studied lakes belong to thermally stratified lakes, in which oxygen depletion occurs in summer in the hypolimnion. The lakes were characterized by a low mean concentration of chlorophyll- $a$ and TSS, indicating that lakes belong to the meso-eutrophic state. Analysis of organic matter and phosphorus content in the sediment depth profile showed that they did not change significantly, indicating steady-state external conditions. The Osgood Index was higher than 6.0 for both lakes (10.5 for Prawe Lake and 7.8 for Lusowskie Lake) and representing the type of lakes with 

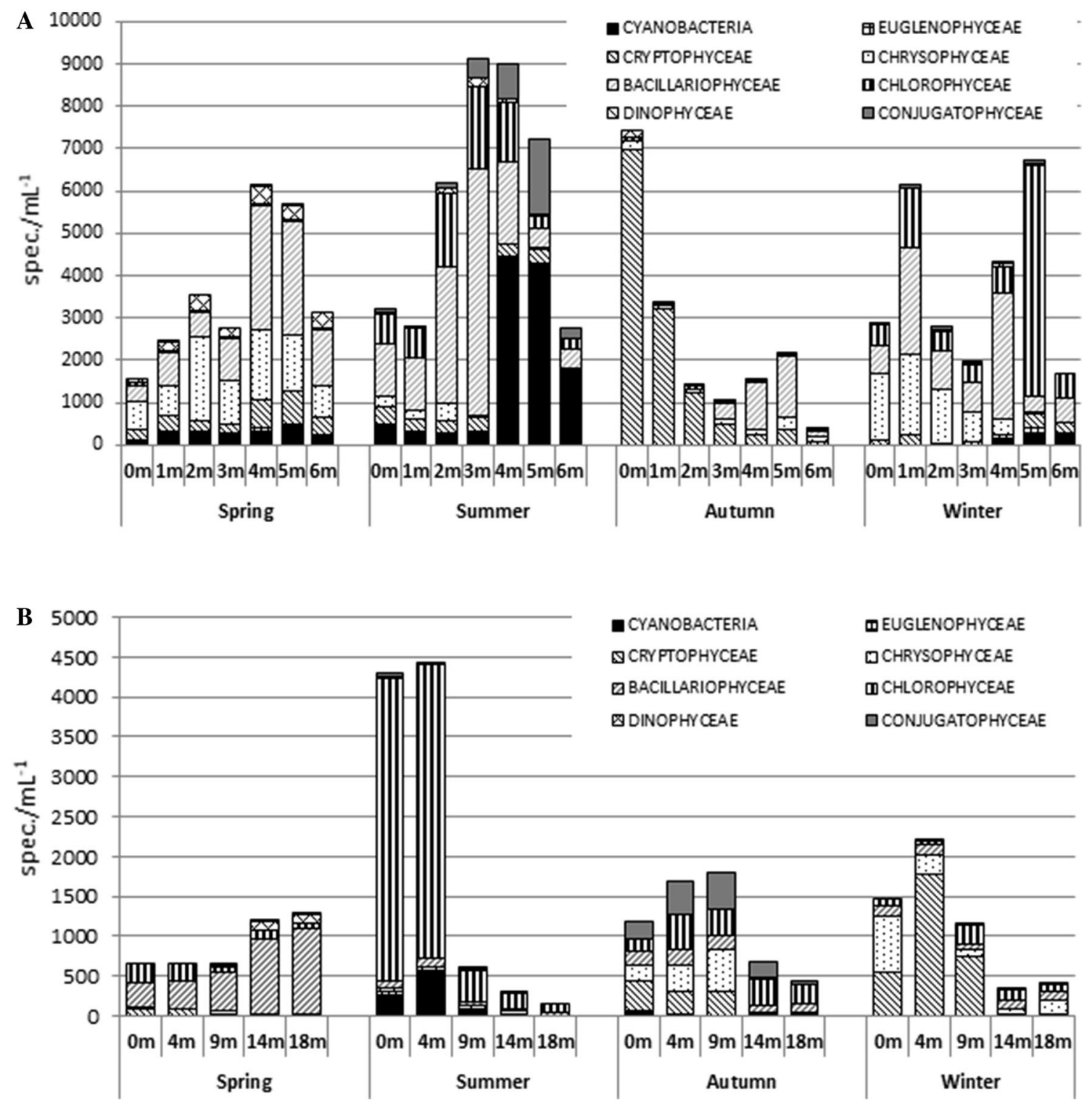

Fig. 5 Abundance of particular phytoplankton groups in Prawe Lake (a) and Lusowskie Lake (b) in the depth profile during the study period

moderate vertical P transport, which should not have a significant effect on algal blooms (Mataraza and Cooke 1997).

Higher rates of $\mathrm{P}$ release were found in the case of the bottom sediments of both lakes from the deepest part of the lake (profundal zone) than from the littoral zone, at a depth of about $2 \mathrm{~m}$. This is a confirmation of the known relationship in limnological literature (Boström et al. 1982; Søndergaard et al. 2001; Kowalczewska-Madura et al. 2015).

Anaerobic conditions at the sediment-water interface in deeper parts of the lakes can stimulate $\mathrm{P}$ release from bottom sediments (Boström et al. 1982, Nürnberg 1988). The twofold higher values of $\mathrm{P}$ release recorded in Prawe Lake was probably due to quite variable oxygen and thermal conditions during the year in the hypolimnion of the smaller and shallower Prawe Lake, in comparison with the stable hypolimnion of Lusowskie Lake. In Prawe Lake, oxygen deficits were found only in summer, but in Lusowskie Lake well oxygenated overlying water occurred mostly in spring. Autumn water mixing in Prawe Lake was easier in depth profile than in Lusowskie Lake, which depended on its small depth, although its small area and vicinity of the forest were not conducive to wind mixing. Early autumn mixing caused an increase in temperature and oxygen concentration at the bottom, which intensified organic matter mineralisation and as a result significantly higher $\mathrm{P}$ release (Boström et al. 1982, Søndergaard et al. 2001; Joniak and Kuczyńska-Kippen 2010). As a result of water mixing in this lake, the gradient of $\mathrm{P}$ concentration was very sharp at 
Fig. 6 Seasonal changes of TP (a) and organic matter content (b) in bottom sediments of the studied lakes
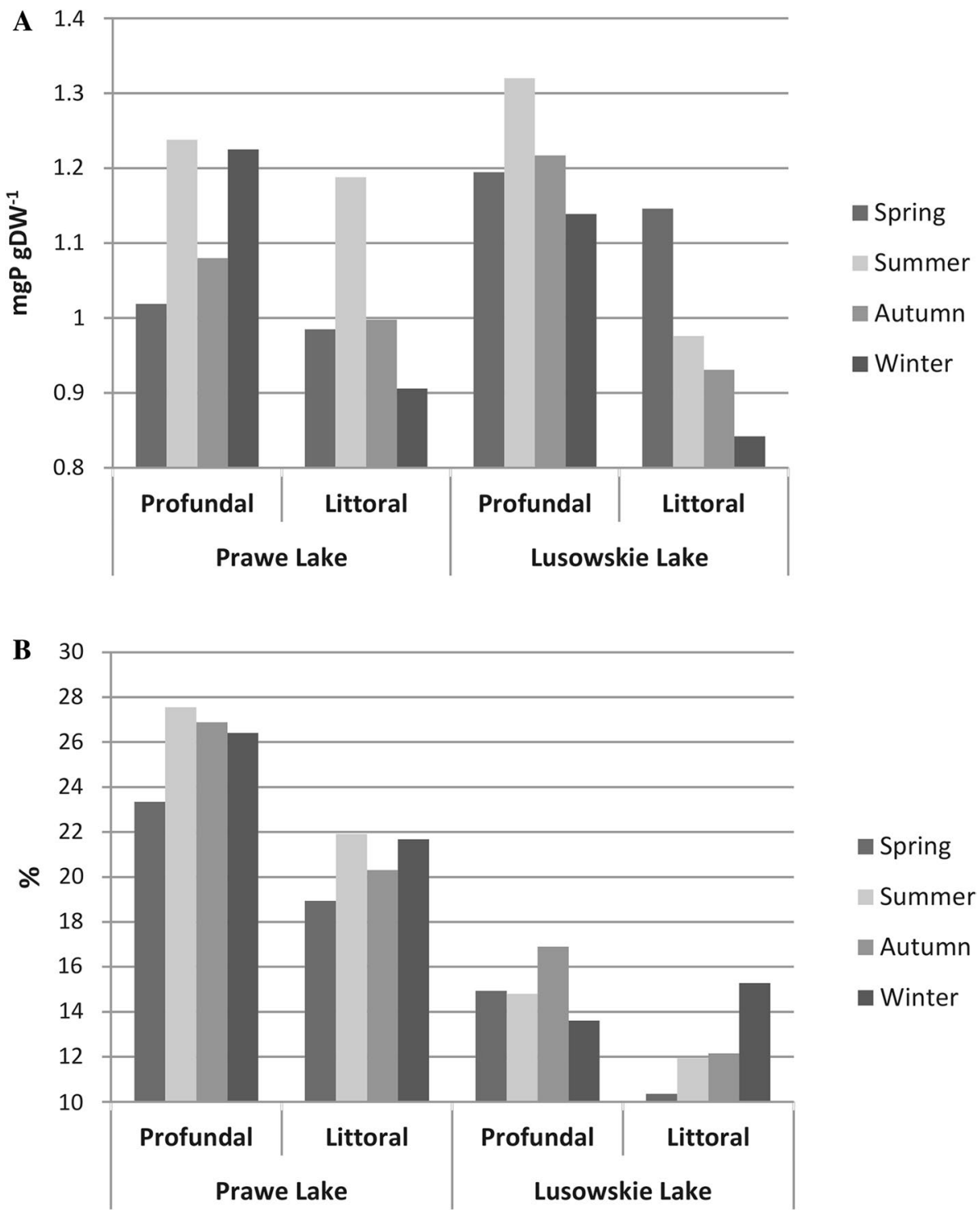

the sediment-water interface, significantly increasing $\mathrm{P}$ diffusion from bottom sediments. Furthermore, the intensity of $\mathrm{P}$ release in autumn was also influenced by more rapid temperature decrease in the water overlying sediments than inside the sediments, which led to a convective instability in pore water with high nutrient concentration stimulating the $P$ release (Golosov and Ignatieva 1999). Significant P release from sediments in autumn was also noted in other lakes situated in the course of the River Cybina, namely, Swarzędzkie Lake and Uzarzewskie Lake, which are also 7 m deep (Kowalczewska-Madura and Gołdyn 2009; Kowalczewska-Madura et al. 2015, 2017). High release was also observed in autumn in Rusałka Lake (9 m deep) (Kowalczewska-Madura et al. 2008, 2011).

Environmental conditions in the over-bottom layer in the profundal zone of the deeper and bigger Lusowskie Lake were more stable during the year than in Prawe Lake.
Incomplete water mixing in late autumn and for a short period in early spring, anaerobic conditions and low temperature of water overlying the sediments in the hypolimnion, contributed to the low $\mathrm{P}$ release from sediments, which was similar in all seasons (Kruskall-Wallis test $p>0.05$ ). Similar weak seasonal variability of internal loading was observed in the $18 \mathrm{~m}$ deep meso-eutrophic Strzeszyńskie Lake, which also had very short or incomplete autumn water mixing (Szeląg-Wasielewska 2006; Kowalczewska-Madura et al. 2015).

Related factors that have been identified as controlling benthic $\mathrm{P}$ release are, besides temperature and dissolved oxygen, also nitrate, $\mathrm{pH}$, and wind strength. The presence of nitrate can reduce benthic $\mathrm{P}$ release from hypolimnetic sediments, because, due to the denitrification process, the redox conditions are improved, despite the absence of dissolved oxygen (Søndergaard et al. 2002). Kleeberg and Kozerski 
Table 2 Mean values \pm SD of various $\mathrm{P}$ forms in the bottom sediments, interstitial water and overlying water at two stations in Prawe lake and Lusowskie lake throughout the study

\begin{tabular}{|c|c|c|c|c|c|}
\hline \multirow[t]{2}{*}{ Parameter } & \multirow[t]{2}{*}{ Unit } & \multicolumn{2}{|l|}{ Prawe Lake } & \multicolumn{2}{|c|}{ Lusowskie Lake } \\
\hline & & Profundal & Littoral & Profundal & Littoral \\
\hline \multicolumn{6}{|c|}{ Bottom sediments } \\
\hline $\mathrm{TP}$ & $\mathrm{mg} \mathrm{Pg}^{-1} \mathrm{DW}$ & $1.14(0.1)$ & $1.02(0.12)$ & $1.22(0.08)$ & $0.97(0.13)$ \\
\hline $\mathrm{NH}_{4} \mathrm{Cl}-\mathrm{P}$ & $\%$ & $8.56(1.5)$ & $3.99(1.3)$ & $3.97(1.3)$ & $2.02(1.0)$ \\
\hline BD-P & $\%$ & $10.35(0.9)$ & $11.82(3.4)$ & $3.39(1.2)$ & $3.14(1.6)$ \\
\hline $\mathrm{NaOH}-\mathrm{P}$ & $\%$ & $2.26(1.3)$ & $5.14(2.7)$ & $5.08(1.9)$ & $2.61(1.9)$ \\
\hline $\mathrm{NaOH}-\mathrm{NRP}$ & $\%$ & $29.31(4.3)$ & 32.44 (1.6) & $29.69(2.3)$ & $19.56(3.2)$ \\
\hline $\mathrm{HCl}-\mathrm{P}$ & $\%$ & $9.0(1.8)$ & $13.84(1.4)$ & $16.99(3.1)$ & $27.1(6.6)$ \\
\hline Res-P & $\%$ & $40.5(5.1)$ & $32.7(6.5)$ & $40.9(3.4)$ & $45.5(7.4)$ \\
\hline $\mathrm{OM}$ & $\%$ & $26.1(1.9)$ & $20.7(1.4)$ & $15.1(1.4)$ & $12.4(2.1)$ \\
\hline \multicolumn{6}{|c|}{ Interstitial water } \\
\hline SRP & $\mathrm{mg} \mathrm{P} \mathrm{L}^{-1}$ & $1.67(0.20)$ & $0.24(0.18)$ & $1.96(0.21)$ & $0.71(0.17)$ \\
\hline $\mathrm{TP}$ & $\operatorname{mg~P~L~}{ }^{-1}$ & $1.91(0.14)$ & $0.44(0.18)$ & $2.37(0.36)$ & $0.84(0.19)$ \\
\hline \multicolumn{6}{|c|}{ Overlying water } \\
\hline SRP & $\mathrm{mg} \mathrm{P} \mathrm{L}^{-1}$ & $0.14(0.08)$ & $0.04(0.03)$ & $0.48(0.29)$ & $0.21(0.18)$ \\
\hline $\mathrm{TP}$ & $\mathrm{mg} \mathrm{P} \mathrm{L}^{-1}$ & $0.26(0.09)$ & $0.11(0.04)$ & $0.55(0.28)$ & $0.27(0.16)$ \\
\hline
\end{tabular}

(1997) found that the concentration of nitrates $>1 \mathrm{mgN} \mathrm{L}^{-1}$ can buffer the redox potential of the surface sediments enough to prevent the release of iron-bound P. The concentration of nitrates in the water overlying the sediments of Lusowskie Lake was present throughout the year, while in Prawe Lake, it disappeared in summer. This was probably the main reason for differences between these lakes in $\mathrm{P}$ release in summer from profundal sediments. The role of nitrates in limiting the internal $\mathrm{P}$ loading was demonstrated during the restoration of Uzarzewskie Lake, where as a result of an innovative method of supplying nitrates to the bottom of the lake, the internal $\mathrm{P}$ loading was reduced by over $80 \%$ (Kowalczewska-Madura et al. 2017). The lower concentration of nitrates and higher organic matter content found in Prawe Lake was a result of the use of the adjacent catchment, which was dominated by forest. The presence of nitrates in summer in the deeper Lusowskie Lake resulted from a greater supply of groundwater from the agricultural catchment. The adjacent catchment area has strong effect on the functioning of the entire ecosystem (Kuczyńska-Kippen et al. 2009; Gołdyn et al. 2015; Wilk-Woźniak et al. 2016).

The lower content of organic matter in the sediments of Lusowskie Lake confirms that the level of sediment mineralization is greater in deep lakes due to longer sedimentation time (Kentzer 2001). The higher organic matter content is also a probable cause of higher $\mathrm{P}$ release from the deepest part of Prawe Lake, compared to the corresponding part of Lusowskie Lake. Prawe Lake is characterized by greater phytoplankton productivity, higher chlorophyll- $a$ concentration and TSS content and its accumulation, especially in the profundal zone. The abundance of phytoplankton in Prawe Lake in summer was about twofold higher than in Lusowskie Lake. Moreover, cyanobacteria constituted a significant share in the species composition of phytoplankton in this period. Their greater abundance was observed near the bottom, in the depth range of 4-6 m. Increased chlorophyll- $a$ concentration was also noted in this zone. Phytoplankton remnants belong to easy-decomposing organic matter particles, which influence higher $\mathrm{P}$ release from bottom sediments. Intensive aerobic and anaerobic decomposition processes can mobilize part of organic $\mathrm{P}$ during settling through the water column (Hupfer and Lewandowski 2008), but this process hardly occurred at all in Prawe Lake due to the phytoplankton growth near the bottom.

Qualitative and quantitative phytoplankton composition shows that the water quality of Prawe Lake was slightly different to that of Lusowskie Lake. Functioning groups C, J, $\mathrm{P}, \mathrm{X} 2, \mathrm{X} 3$, and cryptomonad flagellates Y (Reynolds et al. 2002; Padisak et al. 2009) were dominant in both lakes. They are typical of the mixing layers of meso-eutrophic shallow, clean lakes and are sensitive to lake mixing (Reynolds et al. 2002). The main differences between the lakes lay in a high share of codon D, F and X1 in Lusowskie Lake, and S1 and Lo in Prawe Lake. The group of species represented by codon S1, characteristic of the lake's bad ecological status (Napiórkowska-Krzebietke et al. 2017), represented up to $64 \%$ of phytoplankton abundance in Prawe Lake, while in Lusowskie Lake only $4 \%$. In addition, the greater phytoplankton abundance, including the share of cyanobacteria, was higher in Prawe Lake.

The higher value of phytoplankton diversity in Lusowskie Lake also confirms the better quality of water. The Shannon-Weaver diversity index varied from 0.85 to 2.58 in Lusowskie Lake. This was a little higher than that noted in Prawe Lake. Ranges of values were similar to those recorded in mesotrophic Dejguny Lake (Napiórkowska-Krzebietke 
Fig. 7 Changes of percentage share of extractable fractions of TP in individual seasons in the bottom sediments of Prawe Lake (a) and Lusowskie Lake (b)

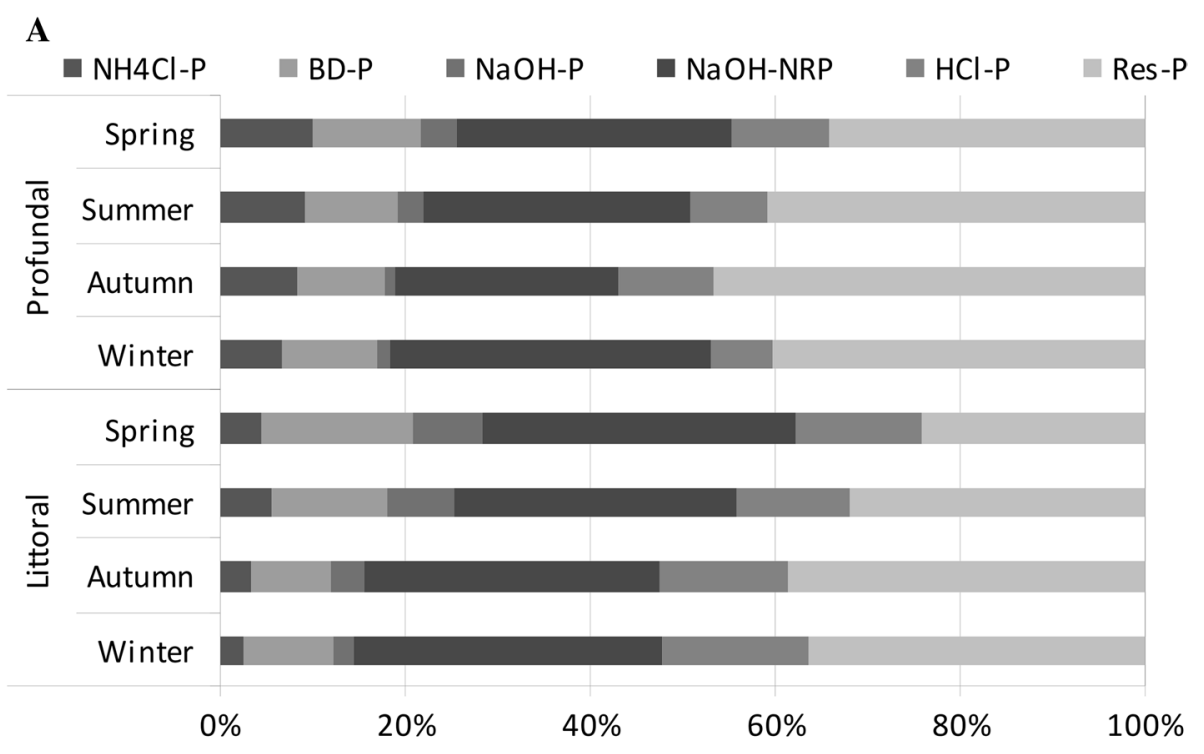

B

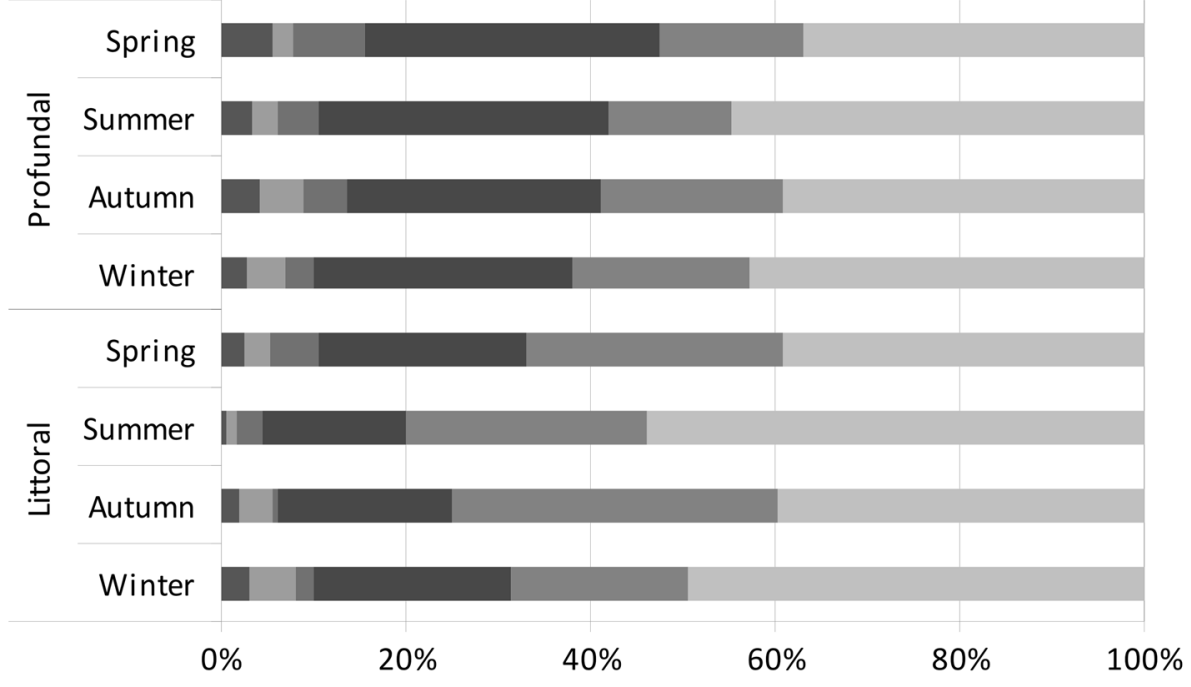

and Hutorowicz 2014) or eutrophic Licheńskie Lake and Ślesińskie Lake (Napiórkowska-Krzebietke 2009). The diversity was higher than noted in shallow hypertrophic Syczyńskie Lake (Toporowska and Pawlik-Skowrońska 2014). An increase in the value of phytoplankton diversity during lake restoration is usually associated with the improvement of water quality, which has been demonstrated in several lakes (Gołdyn et al. 2014; Kozak et al. 2017, 2018).

The intensity of the internal P-loading process was significantly lower in the littoral zone, where good oxygenation of water overlying the sediments was observed throughout the whole year. The shallow part of the lakes with welloxidized conditions prevented $P$ release, because it caused the high redox potential of sediments and accumulation of $\mathrm{P}$ on Fe, Mn, and other metal compounds (Søndergaard et al. 2001, 2002, 2003). Furthermore, some net $P$ accumulation in bottom sediments of Prawe Lake in autumn was also noted. In the literature, however, there are data stating that $\mathrm{P}$ release occurs not only in anaerobic conditions, but also in oxygen presence (Andersen and Ring 1999). The explanation is that under oxygenated water column conditions, hypoxia often develops at the sediment-water interface or within the sediment below its surface (Steinman and Ogdahl 2015). These, usually, short-term changes of oxygen conditions are related to windless weather or high temperature, leading to periodic $P$ release.

Sediments can also be a net source of $\mathrm{P}$ during particular times of the year, e.g., after stronger sedimentation of organic matter as a result of water bloom decay or after a distinct external P load reduction (Hupfer and Lewandowski 2008). Under oxic conditions, $P$ release as a result of the mineralisation of organic matter is primarily controlled through the sorption capacity of sediments, varying due to 
A
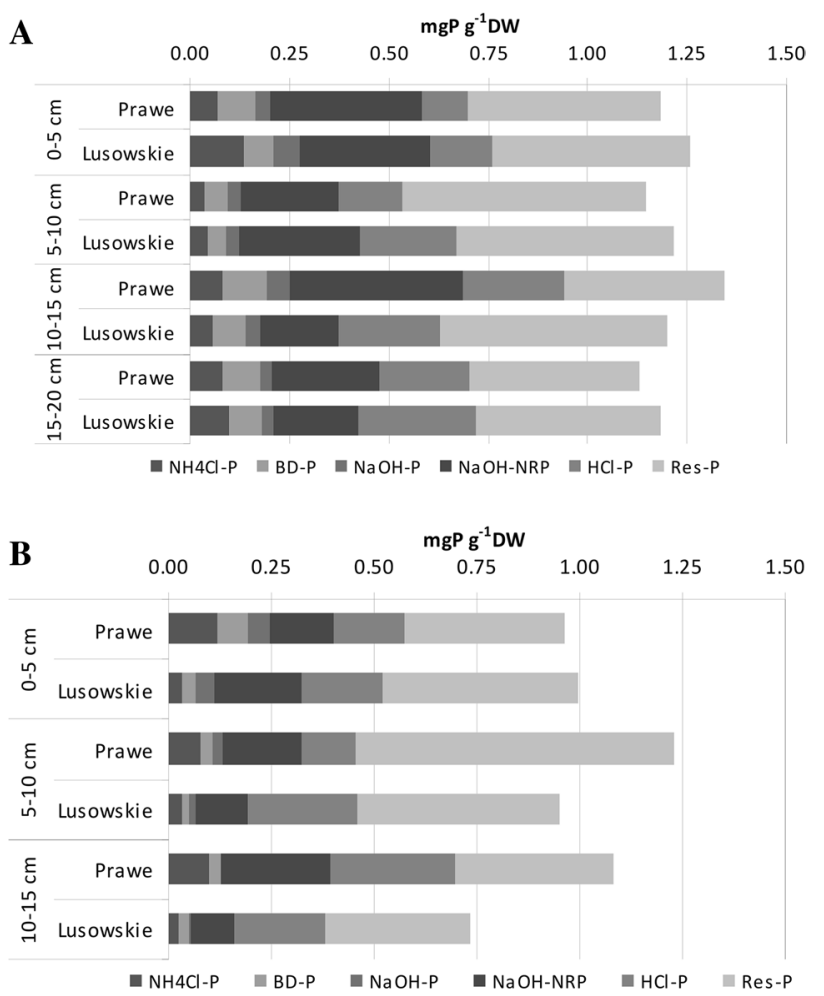

C

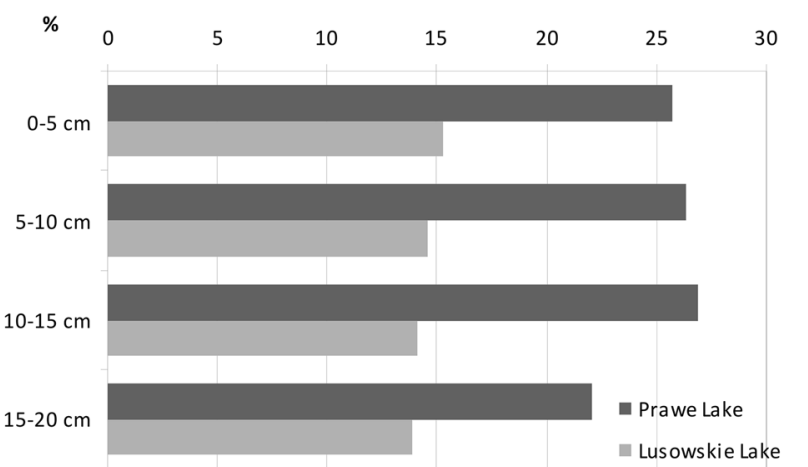

D

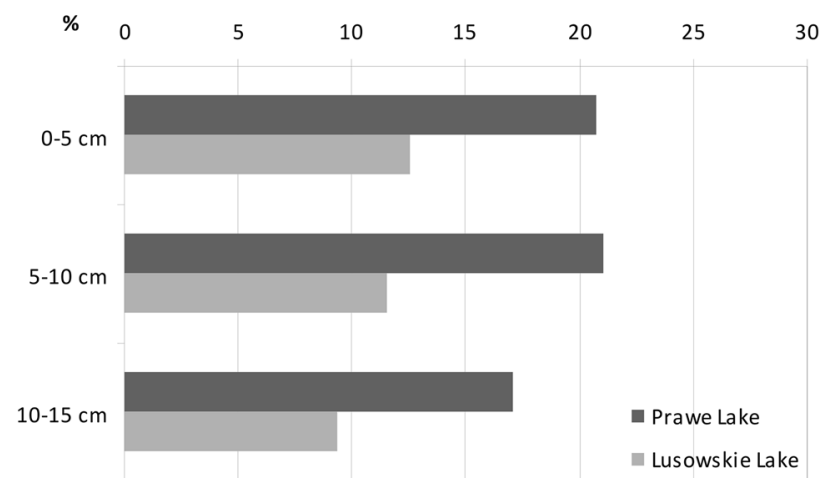

Fig. 8 Concentraction of TP and its extractable fractions in bottom sediment profile in Prawe Lake and Lusowskie Lake in the profundal zone (a) and in the littoral zone (b) and content of organic matter in both lakes in the profundal zone (c) and in the littoral zone (d)
$\mathrm{pH}$ increase and/or anion competition (Boström 1984). It is lower in the littoral zone probably due to less organic matter content in sediments than in the profundal zone. We noted a lower concentration of organic matter in the littoral sediments of both lakes. Because of the resuspension process, fine organic matter from the littoral sediments is partly mineralised within the epilimnetic water and partly sedimented to the profundal zone. This was probably the reason for the lower content of organic matter in the littoral zone of Lusowskie Lake, because its larger surface area and location of the longitudinal axis parallel to the prevailing wind direction promoted sediment resuspension. Organic matter present in the littoral sediments, originated mainly from macrophytes, is not as easily degradable as fine matter originated from phytoplankton, present in the profundal zone (Boström et al. 1982; Søndergaard et al. 2001; Xie 2006).

$\mathrm{P}$ concentrations in pore water and above the sediments are commonly regarded as indices of the intensity of its transport across the sediment-water interface (Kentzer 2001; Komatsu et al. 2006). It was higher in the profundal than in the littoral zone of both lakes, affecting the higher P release. Nevertheless, we observed a positive relationship between $\mathrm{SRP}$ concentrations in the interstitial water and $\mathrm{P}$ release from bottom sediments only in the profundal zone of Prawe Lake ( $p=0.003, r=0.983)$. In Lake Lusowskie, despite the high concentration of $\mathrm{P}$ in the interstitial water, $\mathrm{P}$ release was low. More important here was the small difference in $\mathrm{P}$ concentration between the interstitial water and water overlying the sediments as a result of the high stability of conditions in this zone.

Both analysed lakes were characterized by a similar TP content in bottom sediments. The release of $\mathrm{P}$ from sediments is a function of its binding as well as its mobility. Chemical extractions of different fractions of $\mathrm{P}$ allow the determination of which portion is potentially mobile or not involved in the exchange process (Psenner 1984; Kleeberg and Kozerski 1997). A predominance of the content of the Res-P fraction in bottom sediments, i.e., $\mathrm{P}$ with less biological accessibility, was noted. This fraction plays almost no role in the process of $\mathrm{P}$ release from bottom sediments, because $\mathrm{P}$ compounds within this fraction are hardly decomposed (Psenner et al. 1988). The contribution of the most mobile fractions is particularly important, i.e., $\mathrm{NH}_{4} \mathrm{Cl}-\mathrm{P}$, BD-P, and NaOH-P (Rydin 2000). The mean share of these fractions was about twice as high in Prawe Lake (especially in the profundal zone), which probably influenced greater $\mathrm{P}$ release from bottom sediments. A significant decrease in the amount of these fractions was noted at both stations in Prawe Lake in autumn, probably caused by the intensive $P$ release to the water overlying bottom sediments (Kentzer 2001).

The second largest share in Prawe Lake and in the profundal of Lusowskie Lake was the fraction $\mathrm{NaOH}-\mathrm{NRP}$, which 
Fig. 9 SRP and TP concentration in overlying (a) and pore waters (b) of bottom sediments in Prawe Lake and Lusowskie Lake
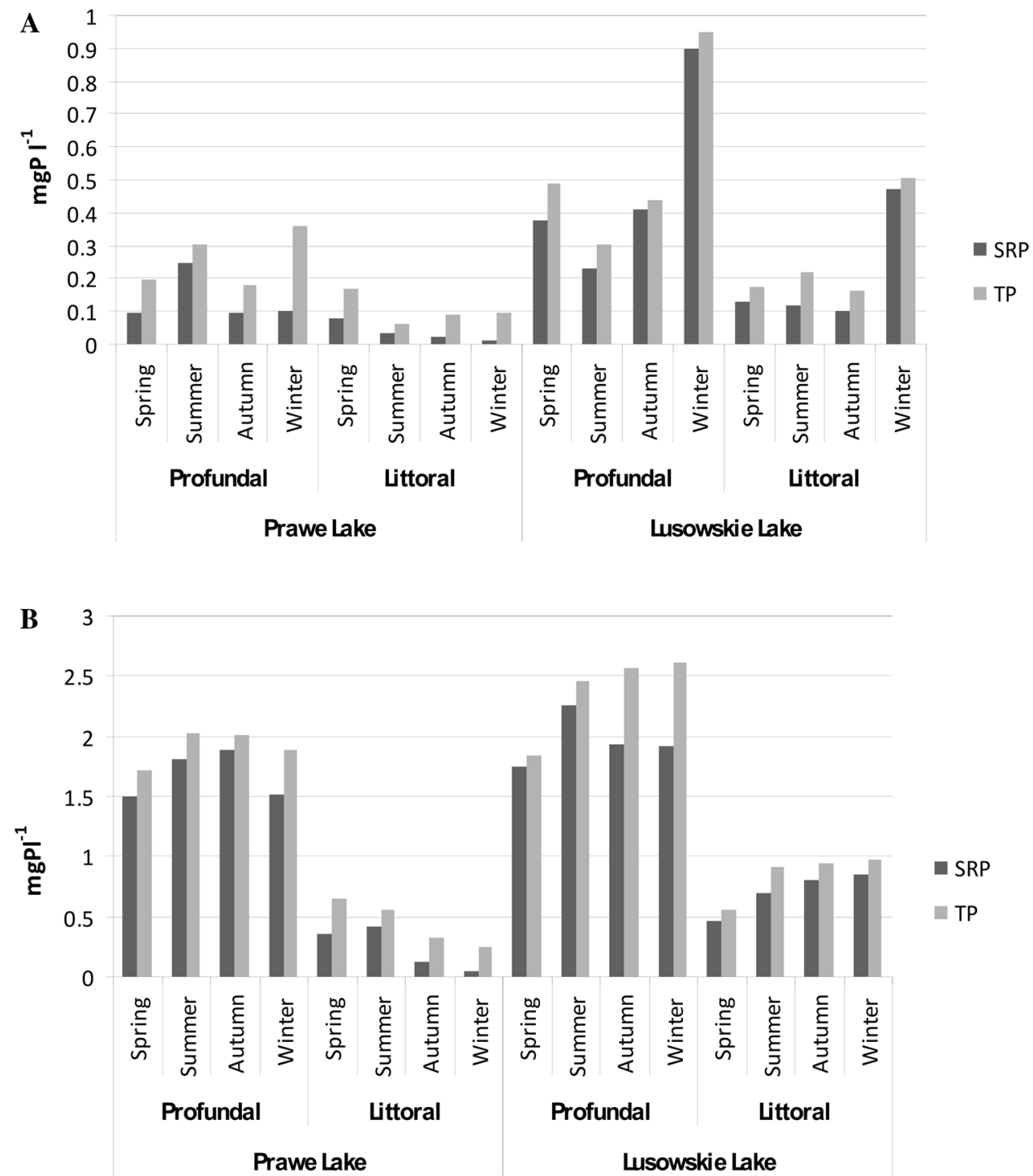

characterized P bound in organic matter (mean over 29\%). The higher share of the NaOH-NRP fraction in Prawe Lake was covered by a higher content of organic matter in bottom sediments and could to some extent stimulate the higher phosphorus release in this lake. Interestingly, a similar content of this fraction in the sediments of the profundal zone of Lusowskie Lake contributed to the much lower P release. The poor availability of oxygen was apparently more important here, hindering the mineralization of this organic matter.

On the other hand, a significant share of the $\mathrm{HCl}-\mathrm{P}$ fraction in the littoral zone of Lusowskie Lake (mean over 27\%) indicated the presence of a large amount of macrophytic remains in the littoral sediments originated from charophytes (Pukacz et al. 2016). The presence of this fraction is not conducive to $\mathrm{P}$ release in this zone (Psenner et al. 1988).

Statistically significant differences between the analysed lakes were recorded for the BD-P fraction (Mann-Whitney $U$ test $p=0.0009)$. A higher content of this fraction at both stations was observed in Prawe Lake, which is probably the result of differences in iron supply from the catchment. This fraction belongs to the easily released $\mathrm{P}$ from the sediments, because it depends on the redox potential, which changes with the oxygen conditions in the sediment-water interphase (Boström et al. 1982; Nürnberg 1988; Gonsiorczyk et al. 1998). Distinct seasonal changes in the content of the BD-P fraction were observed. Its amount decreased in summer in Lusowskie Lake and in autumn in Prawe Lake. This was related to anoxic conditions in the sediments and release of this fraction to the water column.

\section{Conclusions}

The analysis of internal $\mathrm{P}$ loading from bottom sediments in two meso-eutrophic lakes showed its seasonal and spatial heterogeneity. Lake morphometry and adjacent catchment 
Table 3 Physico-chemical parameters in water overlying the sediment cores (mean values \pm SD from three replicates in the experiment) in Prawe lake and Lusowskie lake

\begin{tabular}{|c|c|c|c|c|c|}
\hline \multirow[t]{2}{*}{ Season } & \multirow[t]{2}{*}{ Parameter } & \multicolumn{2}{|l|}{ Prawe Lake } & \multicolumn{2}{|c|}{ Lusowskie Lake } \\
\hline & & Profundal & Littoral & Profundal & Littoral \\
\hline \multirow[t]{4}{*}{ Spring } & Temp. $\left({ }^{\circ} \mathrm{C}\right)$ & $4.4 \pm 0.18$ & $4.4 \pm 0.18$ & $4.8 \pm 0.15$ & $4.8 \pm 0.15$ \\
\hline & Cond. $\left(\mu \mathrm{S} \mathrm{cm}^{-1}\right)$ & $998 \pm 17.68$ & $993 \pm 36.33$ & $804 \pm 14.64$ & $806 \pm 9.11$ \\
\hline & Oxygen $\left(\mathrm{mgO}_{2} \mathrm{~L}^{-1}\right)$ & $8.1 \pm 1.08$ & $9.1 \pm 0.94$ & $6.2 \pm 0.48$ & $6.6 \pm 0.49$ \\
\hline & $\mathrm{pH}$ & $8.10-8.32$ & $8.08-8.50$ & $7.88-8.12$ & $7.90-8.15$ \\
\hline \multirow[t]{4}{*}{ Summer } & Temp. $\left({ }^{\circ} \mathrm{C}\right)$ & $5.1 \pm 0.37$ & $21.6 \pm 0.45$ & $5.3 \pm 0.62$ & $21.2 \pm 0.79$ \\
\hline & Cond. $\left(\mu \mathrm{S} \mathrm{cm}^{-1}\right)$ & $1044 \pm 7.24$ & $1085 \pm 27.68$ & $793 \pm 19.22$ & $795 \pm 43.02$ \\
\hline & Oxygen $\left(\mathrm{mgO}_{2} \mathrm{~L}^{-1}\right)$ & $0 \pm 0$ & $4.5 \pm 1.15$ & $0 \pm 0$ & $5.7 \pm 1.48$ \\
\hline & $\mathrm{pH}$ & $7.20-7.78$ & $7.40-8.05$ & $7.36-7.77$ & $7.46-8.21$ \\
\hline \multirow[t]{4}{*}{ Autumn } & Temp. $\left({ }^{\circ} \mathrm{C}\right)$ & $5.0 \pm 1.27$ & $5.0 \pm 1.27$ & $5.0 \pm 1.38$ & $5.0 \pm 1.38$ \\
\hline & Cond. $\left(\mu \mathrm{S} \mathrm{cm}^{-1}\right)$ & $1012 \pm 17.05$ & $990 \pm 7.54$ & $802 \pm 8.34$ & $763 \pm 8.91$ \\
\hline & Oxygen $\left(\mathrm{mgO}_{2} \mathrm{~L}^{-1}\right)$ & $5.1 \pm 1.01$ & $6.6 \pm 0.32$ & $4.7 \pm 0.52$ & $6.1 \pm 0.78$ \\
\hline & $\mathrm{pH}$ & $7.71-8.08$ & $7.80-8.22$ & $7.40-7.80$ & $7.80-8.00$ \\
\hline \multirow[t]{4}{*}{ Winter } & Temp. $\left({ }^{\circ} \mathrm{C}\right)$ & $4.4 \pm 0.34$ & $4.4 \pm 0.34$ & $4.7 \pm 0.19$ & $4.7 \pm 0.19$ \\
\hline & Cond. $\left(\mu \mathrm{S} \mathrm{cm}^{-1}\right)$ & $1082 \pm 5.81$ & $1035 \pm 8.04$ & $819 \pm 11.53$ & $807 \pm 11.11$ \\
\hline & Oxygen $\left(\mathrm{mgO}_{2} \mathrm{~L}^{-1}\right)$ & $2.4 \pm 1.43$ & $7.0 \pm 1.31$ & $3.9 \pm 0.62$ & $6.1 \pm 0.68$ \\
\hline & $\mathrm{pH}$ & $7.44-7.66$ & $8.08-8.46$ & $7.46-7.85$ & $7.75-8.07$ \\
\hline
\end{tabular}

area (area, depth, shape of the lake basin, and catchment area land use) influences this process as well as differences in the pattern of thermal and oxygen conditions. $\mathrm{P}$ release from bottom sediments of the profundal zone in the shallower Prawe Lake, which was mixing longer, was higher than in Lusowskie Lake with a well-developed and stable hypolimnion. Prawe Lake was characterized by a higher potential for $P$ release due to early mixing in autumn, resulting in increased temperature and oxygenation of sediments as well as lower concentration of nitrates in summer, enabling the reduction of iron compounds and the release of phosphorus. Lower concentration of nitrates and higher organic matter content was dependent on the land use of the adjacent catchment of Prawe Lake, which was dominated by forest. However, taking into consideration the rate of $\mathrm{P}$ released in other lakes with higher trophic state, it can be stated that it was still not high, typical of mesotrophic lakes. Lower P release from the littoral zone was probably due to the lower organic

Table 4 P release (positive values) or accumulation (negative values) $\left(\mathrm{mg} \mathrm{P} \mathrm{m} \mathrm{m}^{-2} \mathrm{~d}^{-1}\right)$ in bottom sediments of Prawe Lake and Lusowskie Lake at both stations (mean values of three replicates) during the study period

\begin{tabular}{llllll}
\hline & \multicolumn{2}{l}{ Prawe Lake } & & \multicolumn{2}{c}{ Lusowskie Lake } \\
\cline { 2 - 3 } \cline { 6 - 6 } \cline { 6 - 6 } & Profundal & Littoral & & Profundal & Littoral \\
\hline Spring & 2.53 & 0.03 & & 2.59 & 0.46 \\
Summer & 4.88 & 0.09 & & 2.01 & 1.67 \\
Autumn & 6.04 & -0.15 & & 1.16 & 0.11 \\
Winter & 3.01 & 0.16 & & 2.56 & 0.19 \\
Mean (SD) & $4.11(1.6)$ & $0.03(0.11)$ & $2.08(0.7)$ & $0.61(0.7)$ \\
\hline
\end{tabular}

matter content and good oxygen conditions. Lusowskie Lake was slightly less exposed to P release from sediments due to its greater depth, which resulted in more rapid mineralization of organic matter during sedimentation and its reduced deposition to bottom sediments. The short and incomplete water mixing in autumn was another important factor due to which higher $\mathrm{P}$ content was found in sediments and higher concentrations of SRP and TP in the interstitial and bottom water. As a result of this mild $\mathrm{P}$ gradient between sediments and water column, its transport to the epilimnion was very limited. In the case of individual P fractions in bottom sediments, the Res-P fraction was dominant in both lakes, but Prawe Lake had a higher share of fractions with high bioavailability (NH4Cl-P, BD-P, and $\mathrm{NaOH}-\mathrm{P}$ ), which resulted in higher $\mathrm{P}$ release from the sediments.

Acknowledgements The study was supported by the Polish Ministry of Science and Higher Education (grant no. 30510831/3632).

\section{Compliance with ethical standards}

Conflict of interest On behalf of all authors, the corresponding author states that there is no conflict of interest.

OpenAccess This article is distributed under the terms of the Creative Commons Attribution 4.0 International License (http://creativeco mmons.org/licenses/by/4.0/), which permits unrestricted use, distribution, and reproduction in any medium, provided you give appropriate credit to the original author(s) and the source, provide a link to the Creative Commons license, and indicate if changes were made. 


\section{References}

Andersen FØ, Ring P (1999) Comparison of phosphorus release from littoral and profundal sediments in a shallow, eutrophic lake. Hydrobiologia 408(409):175-183. https://doi.org/10.1023/A:10170 27818233

Boström B (1984) Potential mobility of phosphorus in different types of lake sediment. Internationale Revue der Gesamten Hydrobiologie und Hydrographie 69:457-474. https://doi.org/10.1002/ iroh.19840690402

Boström B, Jansson M, Forsberg C (1982) Phosphorus release from lake sediments. Arch Hydrobiol 18:5-59

Boström B, Andersen JM, Fleischer S, Jansson M (1988) Exchange of phosphorus across the sediment-water interface. Hydrobiologia 170:229-244. https://doi.org/10.1007/BF00024907

Carey CC, Rydin E (2011) Lake trophic status can be determined by the depth distribution of sediment phosphorus. Limnol Oceanogr 56(6):2051-2063. https://doi.org/10.4319/1o.2011.56.6.2051

Carlson RE (1977) A trophic state index for lakes. Limnol Oceanogr 22(2):361-369

Elbanowska H, Zerbe J, Siepak J (1999) Physico-chemical water analyses. Warsaw PWN publishers 1-232 [in Polish]

Gołdyn R, Grabia J (1998) Program of water protection in the Cybina River. Department of Environmental Protection, Poznań Town's Authority, Poznań [in Polish]

Gołdyn R, Podsiadłowski S, Dondajewska R, Kozak A (2014) The sustainable restoration of lakes - towards the challenges of the water framework directive. Ecohydrol Hydrobiol 14(1):68-74. https:// doi.org/10.1016/j.ecohyd.2013.12.001

Gołdyn B, Kowalczewska-Madura K, Celewicz-Gołdyn S (2015) Drought and deluge: influence of environmental factors on water quality of kettle holes in two subsequent years with different precipitation. Limnologica 54:14-22

Golosov SD, Ignatieva N (1999) Hydrothermodynamic features of mass exchange across the sediment-water interface in shallow lakes. Hydrobiologia 408(409):153-157. https://doi. org/10.1023/A:1017067532346

Gonsiorczyk T, Casper P, Koschel R (1998) Mechanisms of phosphorus release from the bottom sediment of the permanently oxic sediment surface. Arch Hydrobiol 151(2):203-219

Håkanson L (2004) Internal loading: a new solution to an old problem in aquatic sciences. Lakes Reserv Res Manag 9:3-23

Hupfer M, Lewandowski J (2005) Retention and early diagenetic transformation of phosphorus in Lake Arendsee (Germany) - consequences for management strategies. Arch Hydrobiol 164(2):143167. https://doi.org/10.1127/0003-9136/2005/0164-0143

Hupfer M, Lewandowski J (2008) Oxygen controls the phosphorus release from lake sediments-a long-lasting paradigm in limnology. Int Rev Hydrobiol 93(4-5):415-432

Joniak T, Kuczyńska-Kippen N (2010) The chemistry of water and bottom sediments in relation to zooplankton biocenosis in small agricultural ponds. Oceanol Hydrobiol Stud 39(2):85-96

Kentzer A (2001) Phosphorus and its biologically accessible fractions in bottom sediments of lakes of diverse trophic state. The Nicolaus Copernicus University Press, Toruń [in Polish]

Kleeberg A, Kozerski HP (1997) Phosphorus release in Lake Großer Múggelsee and its implications for lake restoration. Hydrobiologia 342(343):9-26

Komatsu E, Fukushima T, Shiraishi H (2006) Modeling of P-dynamics and algal growth in a stratified reservoir-mechanisms of P-cycle in water and interaction between overlying water and sediment. Ecol Model 197:331-349
Kowalczewska-Madura K, Gołdyn R (2009) The internal loading of phosphorus from the sediments of Swarzędzkie Lake (Western Poland). Pol J Environ Stud 18(4):635-643

Kowalczewska-Madura K, Gołdyn R (2010) Models of phosphorus turn-over in a hypertrophic lake: the Lake Swarzędzkie case study. Oceanol Hydrobiol Stud 39(3):21-33

Kowalczewska-Madura K, Dondajewska R, Gołdyn R (2008) Influence of iron treatment on phosphorus internal loading from bottom sediments of the restored lake. Limnol Rev 8(4):177-182

Kowalczewska-Madura K, Dondajewska R, Gołdyn R (2011) Seasonal changes of phosphorus release from the bottom sediments of Rusałka Lake during the restoration process. Ecol Chem Eng A 18(2):219-224

Kowalczewska-Madura K, Gołdyn R, Dera M (2015) Spatial and seasonal changes of phosphorus internal loading in two lakes with different trophy. Ecol Eng 74:187-195. https://doi.org/10.1016/j. ecoleng.2014.10.033

Kowalczewska-Madura K, Dondajewska R, Gołdyn R, Podsiadłowski S (2017) The influence of restoration measures on phosphorus internal loading from the sediments of a hypereutrophic lake. Environ Sci Pollut Res 24:14417-14429. https://doi.org/10.1007/s1135 6-017-8997-2

Kowalczewska-Madura K, Gołdyn R, Bogucka J, Strzelczyk K (2019) Impact of environmental variables on spatial and seasonal internal phosphorus loading in a mesoeutrophic lake. Int J Sediment Res 34:14-26. https://doi.org/10.1016/j.ijsrc.2018.08.008

Kozak A, Gołdyn R, Dondajewska R, Kowalczewska-Madura K, Holona $\mathrm{T}$ (2017) Changes in phytoplankton and water quality during sustainable restoration of an urban lake used for recreation and water supply. Water 9(9):713. https://doi.org/10.3390/w9090713 (1-16)

Kozak A, Rosińska R, Gołdyn R (2018) Changes in the phytoplankton structure due to prematurely limited restoration treatments. Pol J Environ Stud 27:3. https://doi.org/10.15244/pjoes/75956

Kuczyńska-Kippen N, Nagengast B, Celewicz-Gołdyn S, Klimko M (2009) Zooplankton community structure within various macrophyte stands of a small water body in relation to seasonal changes in water level. Oceanol Hydrobiol Stud 38(3):125-133

Lorenzen CJ (1967) Determination of chlorophyll and phaeopigments: spectrophotometric equations. Limnol Oceanogr 12:343-346

Mataraza LK, Cooke GD (1997) A test of a morphometric index to predict vertical phosphorus transport in lakes. J Lake Reserv Manag 13(4):328-337

Myślińska E (2001) Organic soils and methods of analysis in laboratory. PWN Publishing, Warsaw [in Polish]

Napiórkowska-Krzebietke A (2009) Diversity and dynamics of phytoplankton in lakes Licheńskie and Ślesińskie in 2004-2005. Arch Pol Fish 17(4):253-265

Napiórkowska-Krzebietke A, Hutorowicz A (2014) Phytoplankton in an ecological status assessment of the vendace-type Lake Dejguny (northeastern Poland). Arch Pol Fish 22:29-40

Napiórkowska-Krzebietke A, Dunalska J, Zębek E (2017) Taxa-specific eco-sensitivity in relation to phytoplankton bloom stability and ecologically relevant lake state. Acta Oecol 81(1):10-21

Nürnberg GK (1988) Prediction of phosphorus release from total and reductant-soluble phosphorus in anoxic lake sediments. Can J Fish Aquat Sci 45:453-462

Nürnberg GK (2009) Assessing internal phosphorus load-problems to be solved. Lake Reserv Manag 25:419-432

Osgood RA (1988) Lake mixis and internal phosphorus dynamics. Archiv für Hydrobiol 113(4):629-638

Padisak J, Crossetti LO, Naselli-Flores L (2009) Use and misuse in the application of the phytoplankton functional classification: a critical review with updates. Hydrobiologia 621:1-19 
Petterson K (1998) Mechanisms for internal loading of phosphorus in lakes. Hydrobiologia 373(374):21-25

PN-EN ISO 6878: 2006. Water quality-Determination of phosphorus-Ammonium molybdate spectrometric method (ISO 6878:2004) ICS: 13.060 .50

Psenner R (1984) Phosphorus release patterns from sediments of a meromictic mesotrophic lake (Piburger See, Austria). Verh Int Verein Limnol 22:219-228

Psenner R, Boström B, Dinka M, Pettersson K, Pucsko R, Sager M (1988) Fractionation of phosphorus in suspended matter and sediment. Archiv für Hydrobiologie Beih Ergebn Limnol 30:98-113

Pukacz A, Pełechaty M, Frankowski M (2016) Depth-dependence and monthly variability of charophyte biomass production: consequences for the precipitation of calcium carbonate in a shallow Chara-lake. Environ Sci Pollut Res 23(22):22433-22442

Pułyk M, Kołodziej L, Przybylska M, Szeremietiew M, Styczeń L (2001) The report on environment condition in Wielkopolska in 2000. Biblioteka Monitoringu Środowiska, Poznań [in Polish]

Reynolds CS, Huszar V, Kruk C, Naselli-Flores L, Melo S (2002) Towards a functional classification of the freshwater phytoplankton. J Plankton Res 5:417-428

Rydin E (2000) Potentially mobile phosphorus in Lake Erken sediment. Water Res 34(7):2037-2042

Søndergaard M, Jensen JP, Jeppesen E (2001) Retention and internal loading of phosphorus in shallow, eutrophic lakes. Sci World 1:427-442. https://doi.org/10.1100/tsw.2001.72
Søndergaard M, Wolter KD, Ripl W (2002) Chemical treatment of water and sediments with special reference to lakes. In: Handbook of Ecological Restoration 1, Cambridge University Press, Cambridge

Søndergaard M, Jensen JP, Jeppensen E (2003) Role of sediment and internal loading of phosphorus in shallow lakes. Hydrobiologia 506-509:135-145

Steinman AD, Ogdahl ME (2015) TMDL reevaluation: reconciling internal phosphorus load reductions in a eutrophic lake. Lake Reserv Manag 31:115-126

Stephen D, Moss B, Phillips G (1997) Do rooted macrophytes increase sediment phosphorus release? Hydrobiologia 342(343):27-34

Szeląg-Wasielewska E (2006) Original research trophic status of lake water evaluated using phytoplankton community structurechange after two decades. Pol J Environ Stud 15(1):139-144

Toporowska M, Pawlik-Skowrońska B (2014) Four-year study on phytoplankton biodiversity in a small hypertrophic lake affected by water blooms of toxigenic cyanobacteria. Pol J Environ Stud 23(2):491-499

Wilk-Woźniak E, Koreiviene J, Karosiene J, Pociecha A, Strzesak M, Mroz W (2016) Contrasting phytoplankton structure and morphologically based functional groups of reservoirs that differ in the adjacent surrounding. Clean-Soil Air Water 44(6):638-647

Xie P (2006) Biological mechanisms driving the seasonal changes in the internal loading of phosphorus in shallow lakes. Sci China Ser D Earth Sci 49:14-27. https://doi.org/10.1007/s11430-006-8102-Z 